\title{
Phylogenetic relationships of the bacchine flower flies (Diptera: Syrphidae) based on molecular characters, with a description of a new species of Melanostoma (Schiner, 1860)
}

\author{
Ximo Mengual \\ Zoologisches Forschungsmuseum Alexander Koenig, \\ Adenauerallee 160, 53113 Bonn, Germany \\ x.mengual@leibniz-zfmk.de
}

\begin{abstract}
The phylogenetic relationships among the genera of the tribe Bacchini sensu lato (i.e., Syrphinae with simple, unsegmented aedeagus) were inferred using molecular evidence. The mitochondrial proteincoding gene cytochrome c oxidase subunit I (COI) and the nuclear ribosomal $28 \mathrm{~S}$ and $18 \mathrm{~S}$ rRNA genes for 54 bacchine taxa were analyzed using Bayesian inference and Maximum Likelihood. Among the analyzed taxa there is a new species of Melanostoma (Schiner) from Cameroon, Melanostoma janeceki Mengual, sp. nov., which is described in full. This new species has a complete metasternum without excavation, a characteristic that is not present in other species of Melanostoma, usually with an excavated metasternum, but it is the diagnostic character of the genus Afrostoma Skevington, Thompson \& Vockeroth. Based on the phylogenetic placement of Melanostomajaneceki Mengual, sp. nov. the taxonomic status of Afrostoma as a genus is discussed and a new generic classification of Bacchini stat. rev. and Melanostomini stat. rev. is presented in the light of the inferred phylogeny. Results did not recover Bacchini sensu lato monophyletic, but into two groups as follows: Melanostoma and related genera, and Baccha, Platycheirus and related genera. Pseudoplatychirus van Doesburg is considered junior synonym of Platycheirus Le Peletier \& Audinet-Serville, and Afrostoma Skevington, Thompson \& Vockeroth as junior synonym of Melanostoma. Pyrophaena Schiner and Eocheilosia Hull comb. nov. are ranked as valid genera, and consequently, the genus Platycheirus is divided into four subgenera: Platycheirus (Carposcalis) (Enderlein), Platycheirus (Pachysphyria) (Enderlein), Platycheirus (Platycheirus), and Platycheirus (Tuberculanostoma) (Fluke) comb. nov.
\end{abstract}

\section{Keywords}

Afrostoma - bacchine - Bacchini - melanostomine - Melanostomini - new synonym 


\section{Introduction}

Commonly known as flower flies or hoverflies, syrphids (Diptera: Syrphidae) are distributed worldwide, absent only in remote oceanic islands and Antarctica (Thompson \& Rotheray, 1998). While adults feed on pollen and nectar, larvae have a large array of natural histories (Ureña \& Hanson, 2010; Rotheray \& Gilbert, 2011; Pérez-Lachaud et al., 2014; Fleischmann et al., 2016). Syrphid species have been used as bioindicators (Sommaggio, 1999; Tscharntke et al., 2005; Ricarte et al., 2011; Sommaggio \& Burgio, 2014), and they contribute to very important ecosystem services, such as pollination, biological control of pests or decomposition of organic matter (Lardé, 1989; Schmidt et al., 2004; Bergh \& Short, 2008; Bugg et al., 2008; Ssymank \& Kearns, 2009; Morales \& Wolff, 2010; Martínez-Falcón et al., 2012; Nelson et al., 2012; Inouye et al., 2015).

The family is currently divided into four subfamilies, namely Microdontinae, Eristalinae, Pipizinae, and Syrphinae (Mengual et al., 2015), although some authors prefer to consider the microdontines as a different family (Thompson, 1969; Speight, 1987, 2018). Phylogenetically, Pipizinae and Syrphinae form a clade (Ståhls et al., 2003; Hippa \& Ståhls, 2005; Mengual et al., 2015; Young et al., 2016a) whose members have primarily predatory larvae (Rotheray, 1993; Rojo et al., 2003; Downes et al., 2017). However, some Syrphinae species have become phytophagous secondarily (Nishida et al., 2002; Weng \& Rotheray, 2008; Reemer \& Rotheray, 2009; Zuijen \& Nishida, 2011; Dumbardon-Martial, 2016). Vockeroth (1969) divided the subfamily Syrphinae into six tribes, namely Bacchini, Melanostomini, Paragini, Toxomerini, Chrysotoxini and Syrphini. Later, Vockeroth (1992) rearranged his tribal system with the currently accepted four tribes: Bacchini, Paragini, Toxomerini, and Syrphini. This current tribal classification of
Syrphinae needs a revision based on recent molecular studies, where Bacchini and Syrphini were never resolved as monophyletic (Mengual et al., 2008a, 2012, 2015; Mengual \& Thompson, 2011; Mengual, 2015; Young et al., 2016a; Pauli et al., 2018).

Classically, Bacchini is defined as Syrphinae taxa with the aedeagus of the male genitalia rather simple, undivided (Vockeroth, 1969, 1992), and face and scutellum entirely black. The coloration of the face and scutellum is no longer a defining characteristic for Bacchini as there are Bacchini species with pale parts of the face (Vockeroth, 1990; Thompson, 1999) and Syrphini species with face and scutellum entirely black (Vockeroth, 1969, 1990; Huo, 2014). The tribe Bacchini sensu lato, hereafter the members of Syrphinae with a simple aedeagus, has undergone several modifications in its definition, mostly due to the concept of the genus Baccha Fabricius, 1805, which ended up to an extremely diverse tribe (Vockeroth, 1969). Bigot (1883) was the first to use a name to refer a suprageneric group, Bacchidae. Since Williston (1885) separated them into Melanostominae and Bacchinae, in almost every case where the author distinguished between Melanostomini (also wrongly written as Melanostomatini; see Sabrosky, 1999) and Bacchini, the latter included several genera and species of Syrphini placed under Baccha (Williston, 1885; Hull, 1949; Wirth et al., 1965; Vockeroth, 1969; Shatalkin, 1975). Thompson et al. (1976) made a major rearrangement redefining the genus Ocyptamus Macquart, 1834 and placing it within Syrphini, which helped in the current definition of Bacchini, but the current concept of Bacchini sensu lato is based mostly on Vockeroth (1992) and Thompson (1999).

Although the members of Bacchini were accepted without major controversy, generic definitions have been unclear and the systematic status of some supraspecific taxa was unstable (Thompson \& Rotheray, 1998; Mengual 
et al., 2008a; Láska et al., 2013; Young et al., 2016a). Young et al. (2016b) gave a precise background on how the genera Platycheirus Le Peletier \& Audinet-Serville, 1828 and Melanostoma Schiner, 1860 have been defined historically. Nowadays the genus Melanostoma only includes species with an excavated metasternum (Andersson, 1970), and the metasternum with an anterior excavation is established as the diagnostic character to separate this genus from the other bacchines (Andersson, 1970; Barkalov, 2009). The latest member to be part of Bacchini sensu lato was described by Thompson \& Skevington (2014), the monotypic genus Afrostoma Skevington, Thompson \& Vockeroth, 2014. Besides the description of their new genus, Thompson \& Skevington (2014) also provided an excellent outline of the tribe Bacchini sensu lato since its origin and gave a synopsis for each genus. Thompson \& Skevington (2014) used DNA barcodes (Hebert et al., 2003a, b) to place their new genus Afrostoma in a phylogenetic context and stated some diagnostic characteristics, i.e., lack of male secondary characters in legs (as in Melanostoma, but usually present in many Platycheirus species), metasternum without basolateral excavation (as in Platycheirus, but the diagnostic character for Melanostoma), antennal pits confluent, and male genitalia without synapomorphies of Platycheirus. At first glance, Afrostoma looks like a Melanostoma without metasternal excavation and male genitalia of Melanostoma species (Fluke, 1957) are overall very similar to those of Afrostoma. Male genitalia characters are rather distinct between Afrostoma and Platycheirus, the two genera close to Melanostoma with metasternum not excavated: i.e., Platycheirus has surstyli with a long, slightly curved lateral lobe, and a short, stout basomedial lobe (surstyli elongate and simple in Afrostoma, with a small tubercle instead of a basomedial lobe); Platycheirus has postgonites usually slender with a hook-like process (postgonites massive, solid, irregular in shape in Afrostoma), and the distiphallus in Platycheirus is slightly expanded at apex (distiphallus notched in Afrostoma) (Fluke, 1957; Thompson \& Skevington, 2014; Young et al., 2016b).

Recent phylogenetic studies have resolved the tribe Bacchini sensu lato into two or three different clades, grouping genera related to Melanostoma in one clade, and genera related to Platycheirus in another (Mengual, 2015; Mengual et al., 2015; Young et al., 2016a), and sometimes, resolving the genus Baccha in its own evolutionary lineage (Rotheray \& Gilbert, 1999; Ståhls et al., 2003; Mengual et al., 2008a). Only the phylogeny by Hippa \& Ståhls (2005) based on morphological characters have inferred all these groups into a single clade. The proposed classification of Shatalkin (1975), with Melanostomini divided into Platycheirina and Melanostomina (see Thompson, 1972), reflects most of the present phylogenetic relationships among Bacchini. In this study, Shatalkin (1975) placed Baccha under Bacchini together with Ocyptamus (currently in Syrphini) and Allobaccha Curran, 1928 (currently also in Syrphini), and his Melanostomini was equivalent to the current Bacchini with the exclusion of Baccha.

The present author gathered molecular data during some years to study more closely the phylogenetic relationships among Bacchini sensu lato. To perform the analysis we used three molecular markers: almost the entire mitochondrial protein-coding gene cytochrome c oxidase subunit I (COI), the $\mathrm{D}_{2}-\mathrm{D}_{3}$ region of the nuclear ribosomal $28 \mathrm{~S}$ rRNA gene, and a small fragment of the nuclear ribosomal $18 \mathrm{~S}$ rRNA gene. The aims of this study are twofold: (i) to infer the phylogenetic relationships of the tribe Bacchini sensu lato based on molecular characters and the largest taxon sampling up-to-date; and (ii) to describe a new species of Melanostoma from Cameroon without 
metasternal excavation. Consequently, a new generic classification of Bacchini stat. rev. and Melanostomini stat. rev. is presented and some taxonomic actions are carried out: Pseudoplatychirus van Doesburg, 1955 is considered junior synonym of Platycheirus and Afrostoma as junior synonym of Melanostoma. Pyrophaena Schiner, 1860 and Eocheilosia Hull, 1949 comb. nov. are ranked as valid genera, and consequently, the genus Platycheirus is divided into four subgenera: Platycheirus (Carposcalis) (Enderlein, 1938), Platycheirus (Pachysphyria) (Enderlein, 1938), Platycheirus (Platycheirus), and Platycheirus (Tuberculanostoma) (Fluke, 1943) comb. nov.

\section{Material and methods}

\section{Taxonomy}

The new species of Melanostoma was collected during the field work done by Vlašánková et al. (2017) in the Mendong Buo area $\left(6.592699^{\circ} \mathrm{N}, 10.189999^{\circ} \mathrm{E} ; 2100-2200 \mathrm{~m}\right.$ above sea level), ca. 5 km south-east of Big Babanki, in the Bamenda Highlands, North-West Province, Cameroon. This new species to science is refereed as Melanostoma sp. in Vlašánková et al. (2017). In the present study, the division between Bacchini sensu stricto and Melanostomini stated by Thompson \& Skevington (2014) will be followed to discuss the results.

New species is described in full with terminology following Thompson (1999) and Cumming \& Wood (2017). In the description of type labels, the contents of each label is enclosed within double quotation (“"), italics denote handwriting, and the individual lines of data are separated by a double forward slash (//). At the end of each record, between square brackets ( [ ] ) and separated by a comma, the number of specimens and sex, the holding institution, and the unique identifier or number are given. The abbreviations used for collections follow the standard of the Systema Dipterorum (Thompson, 2013), and their equivalents are given below:

BMNH: The Natural History Museum, London, UK.

NBC: Naturalis Biodiversity Center, Leiden, The Netherlands.

MNHN: Muséum National d'Histoire Naturelle, Paris, France.

ZFMK: Zoologisches Forschungsmuseum Alexander Koenig, Bonn, Germany.

All measurements are in millimeters and were taken using a reticule in a Leica $\mathrm{M}_{1} 6{ }_{5} \mathrm{C}$ microscope. Photographs were composed using the software Zerene Stacker 1.04 (Richland, Washington, USA), based on images of pinned specimens taken with a Canon EOS ${ }_{7} \mathrm{D}$ mounted on a $\mathrm{P}-5^{1}$ Cam-Lift (Dun Inc., VA, USA) and with the help of Adobe Lightroom (version 5.6). Body length was measured from the anterior oral margin to the posterior end of the abdomen, in lateral view. Wing length was measured from the wing tip to the basicosta.

\section{Taxon sampling for molecular analyses}

The selection of taxa for this study was based on Thompson \& Skevington (2014) (see fig. 1). Members of all genera and subgenera of Bacchini and Melanostomini were included in the analysis, with the exception of Afroxanthandrus Kassebeer, 2000 and Xanthandrus (Androsyrphus) Thompson, 1981 because there were no available specimens for the present molecular study. A total of 90 taxa were used in the analyses, including 54 bacchine and melanostomine taxa. Table 1 lists the species included in the analysis, the collection data and the GenBank accession numbers. Some new species to science, which will be described in following publications, were included as well and they are indicated in fig. 2 as 'sp.n.' plus the lab code in brackets. 


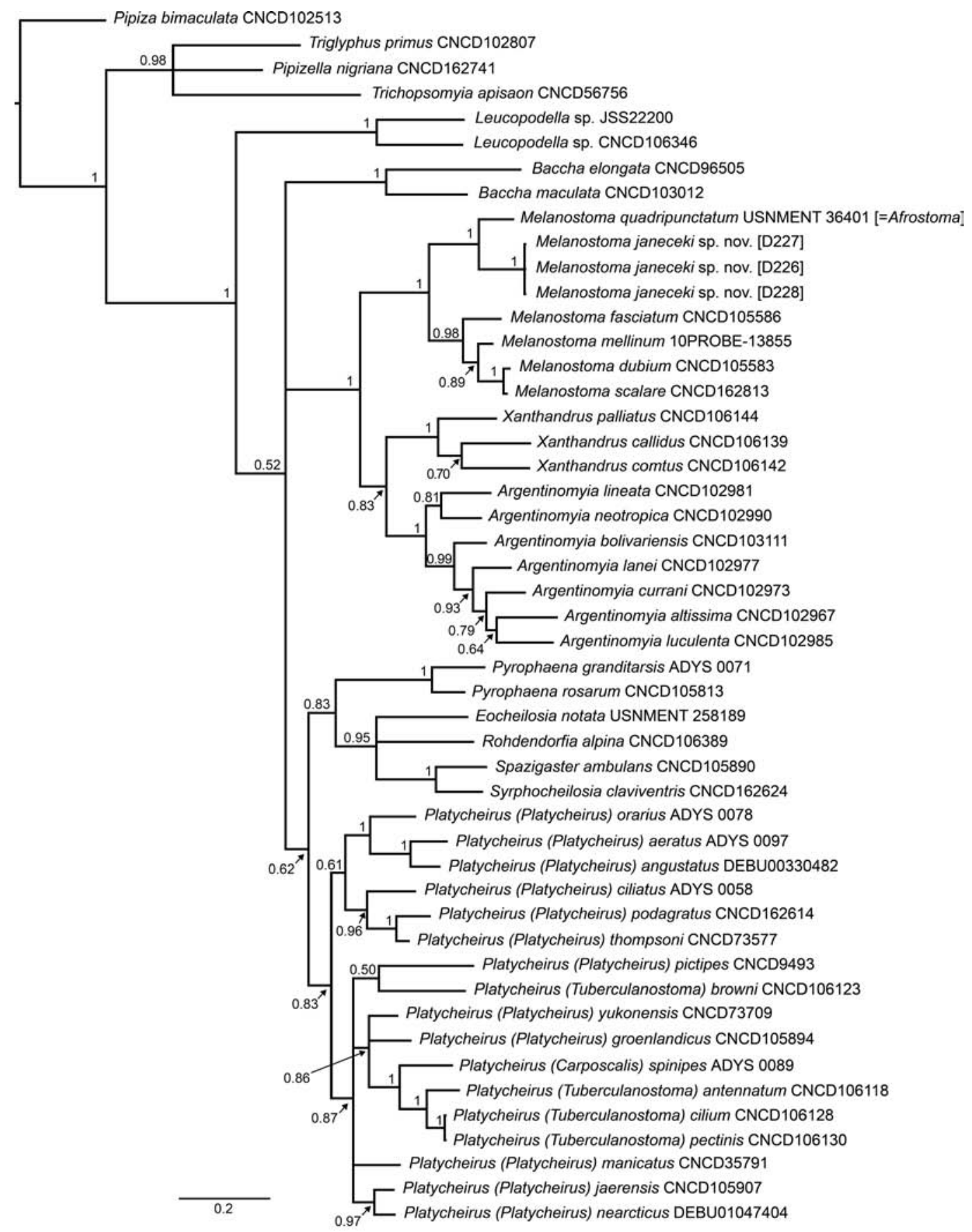

FIGURE $1 \quad 50 \%$ majority rule consensus cladogram produced from Bayesian analysis of COI data. Bayesian posterior probabilities are shown at each node.

Outgroups and the Syrphini taxa included in this work were selected based on previous phylogenetic works and current knowledge.
Microdon mutabilis (Linnaeus, 1758) was constrained as outgroup as all previous phylogenies resolved Microdontinae as the sister Downloaded from Brill. como4/26/2023 09:04:30AM 


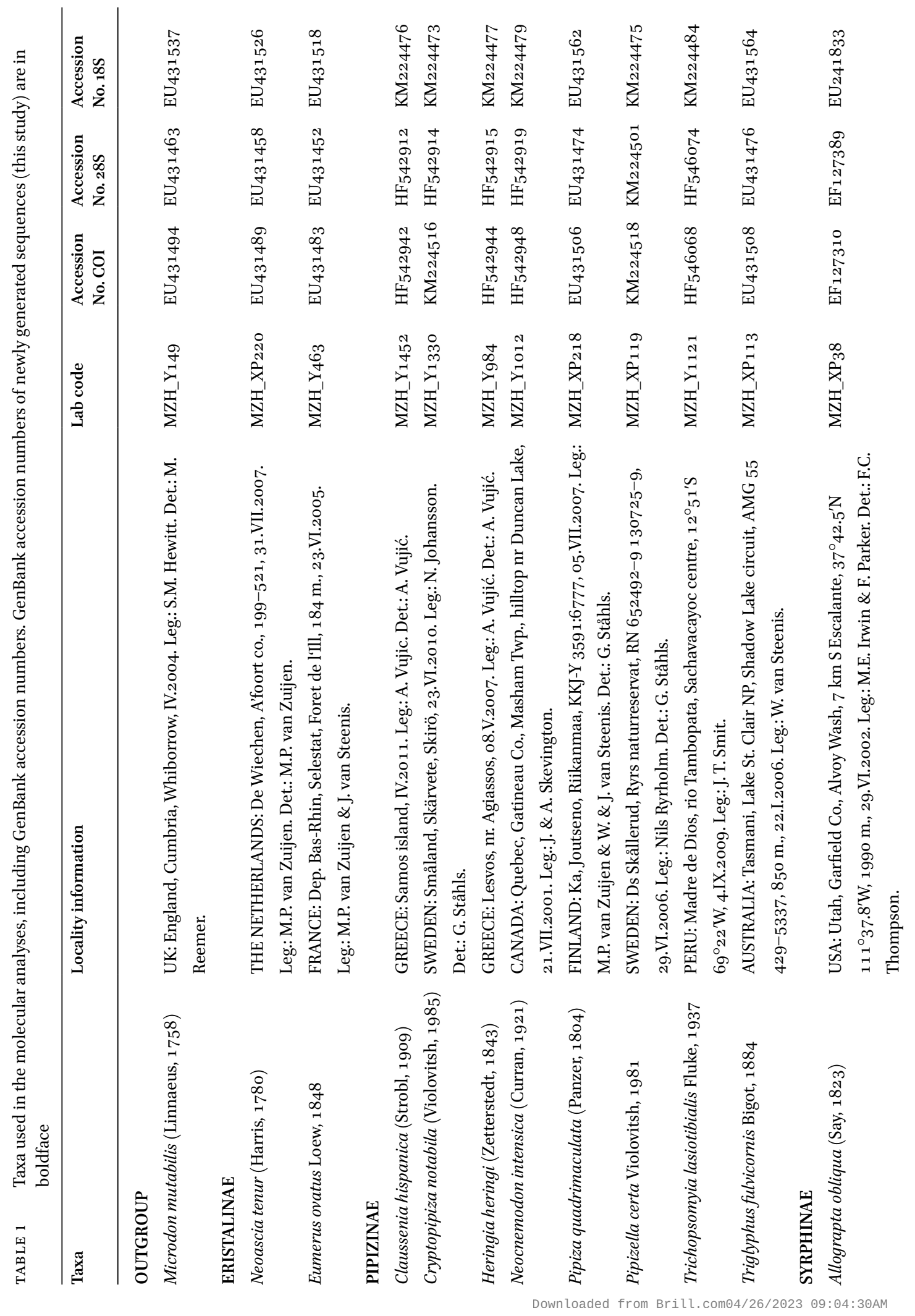




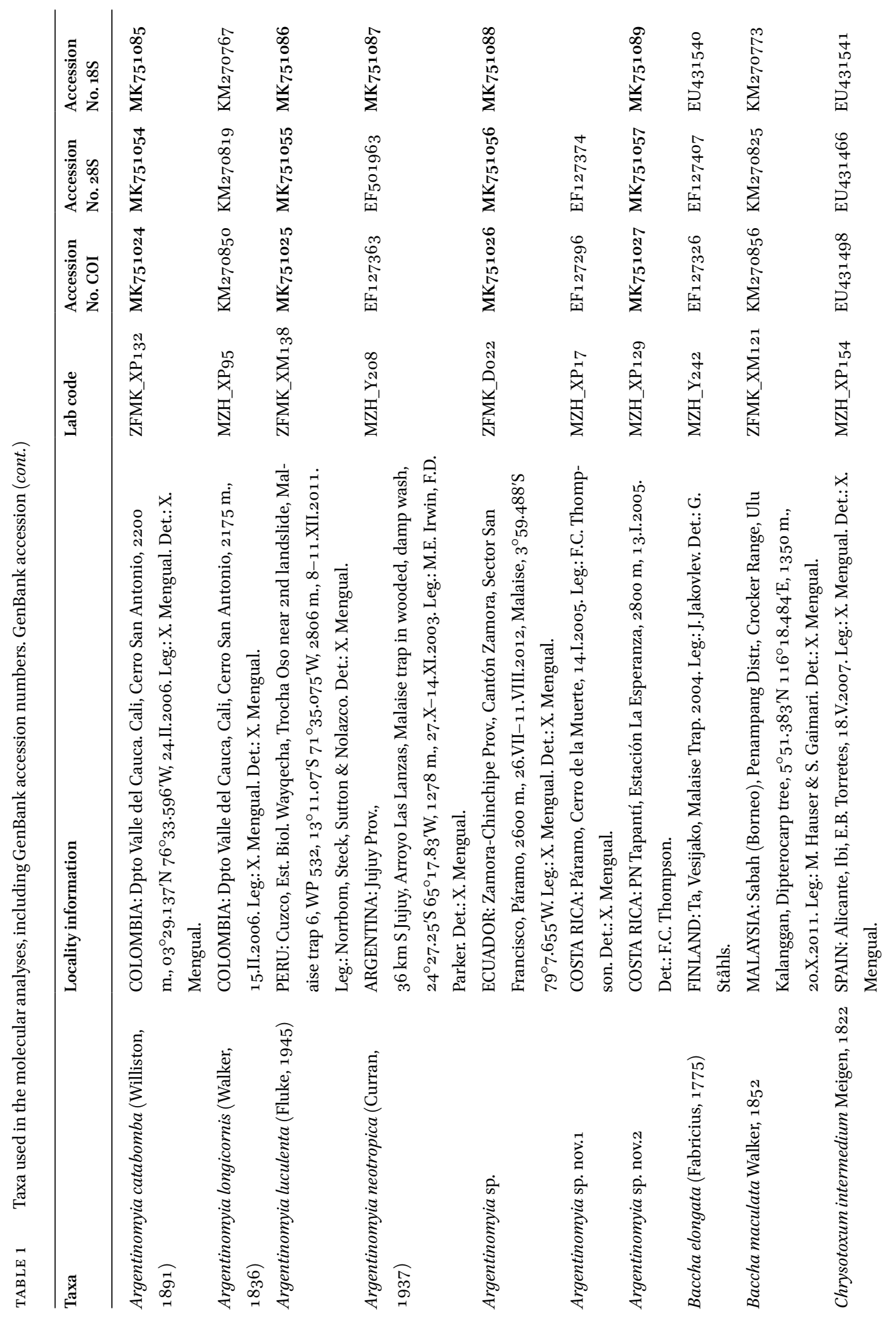




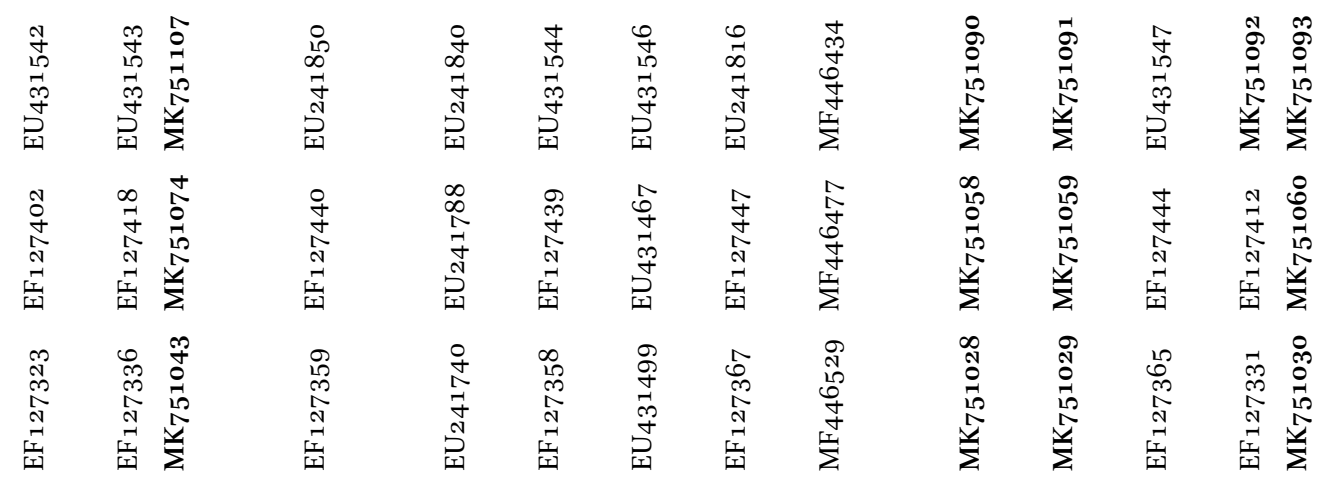

$\begin{array}{lllllllll}0 & \\ 0\end{array}$

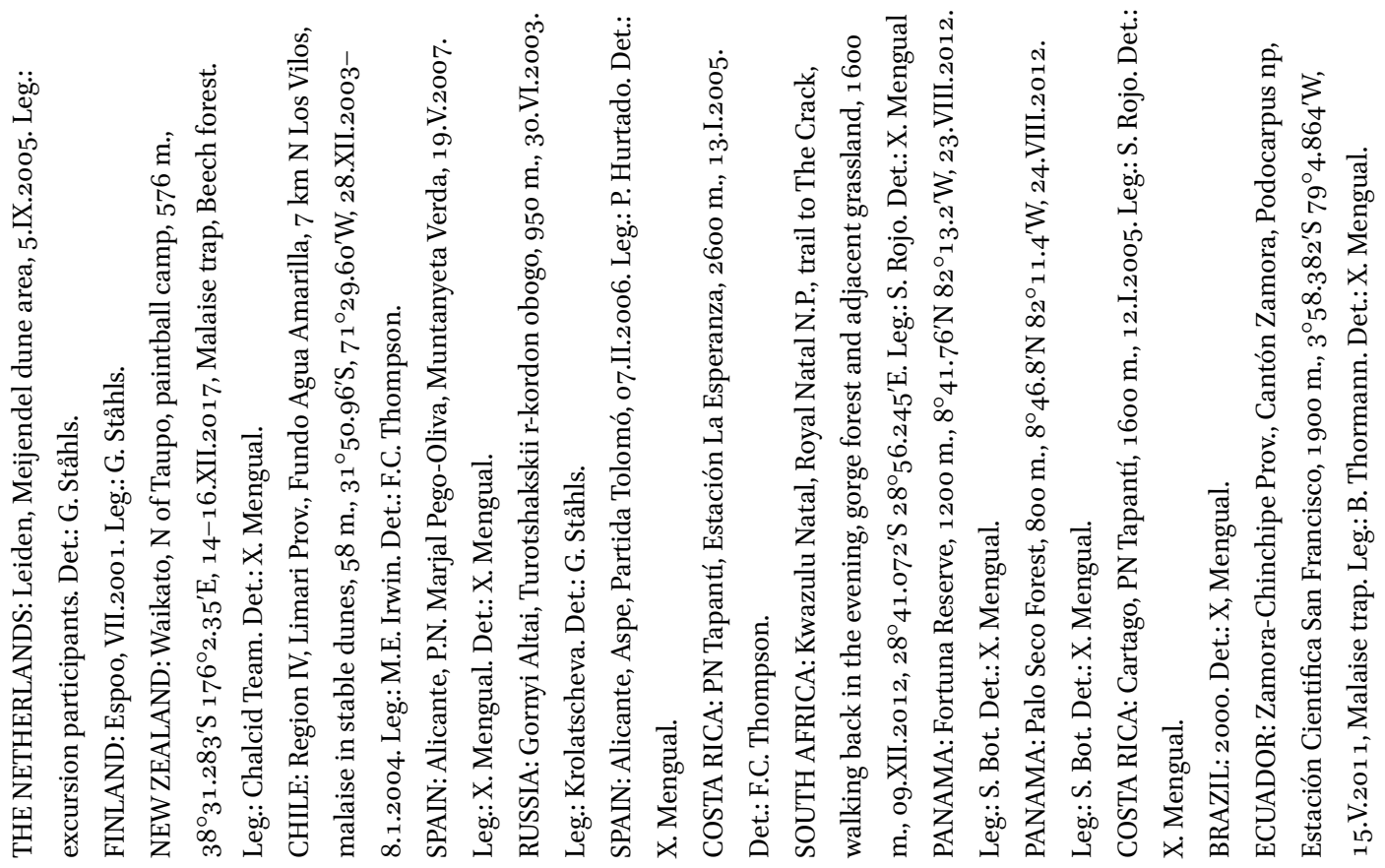

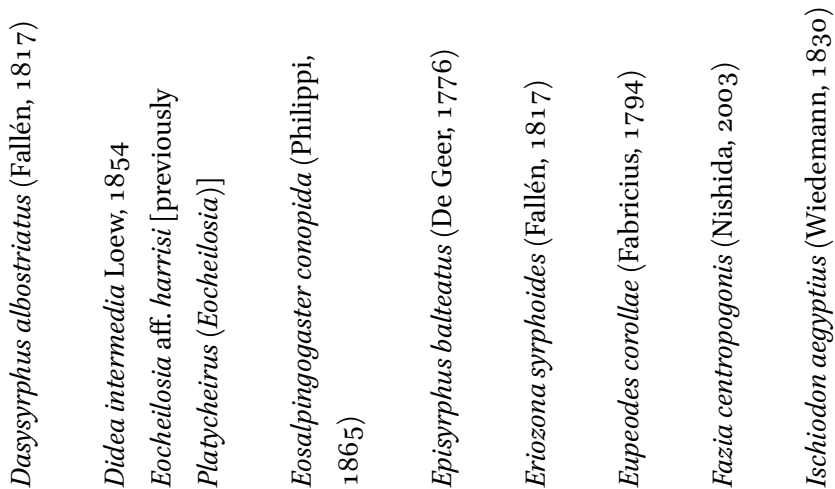

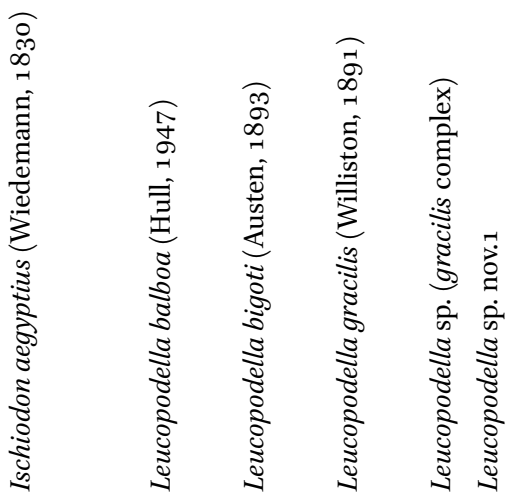




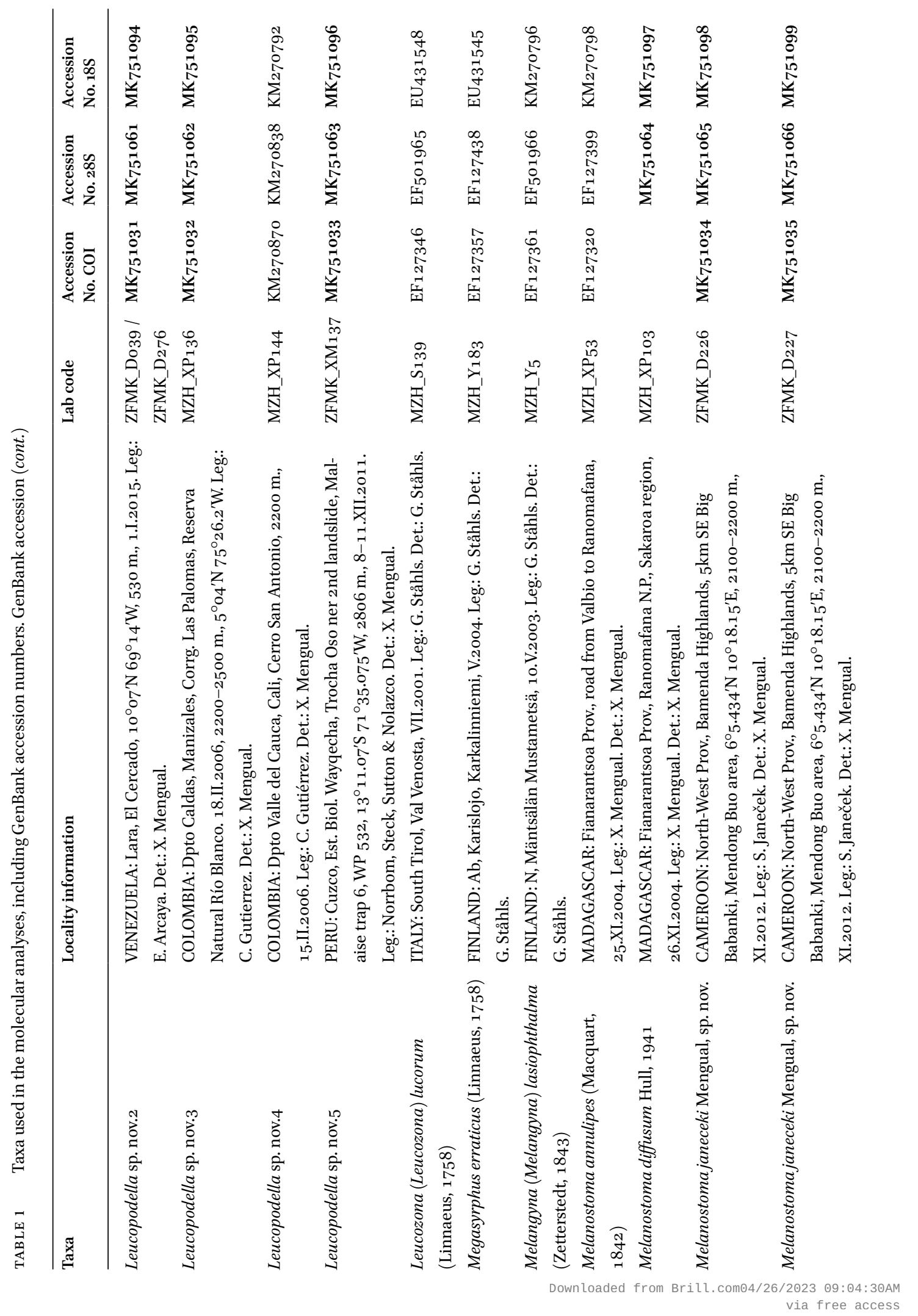




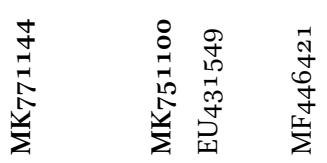

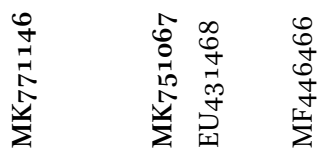

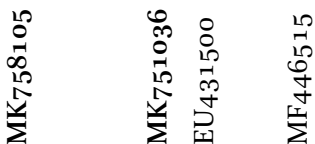

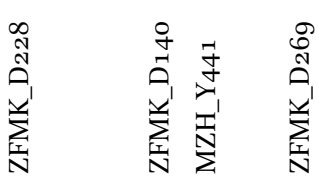

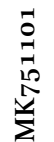

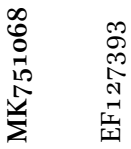

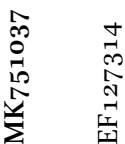

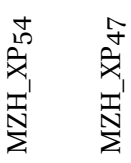

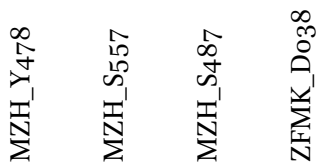

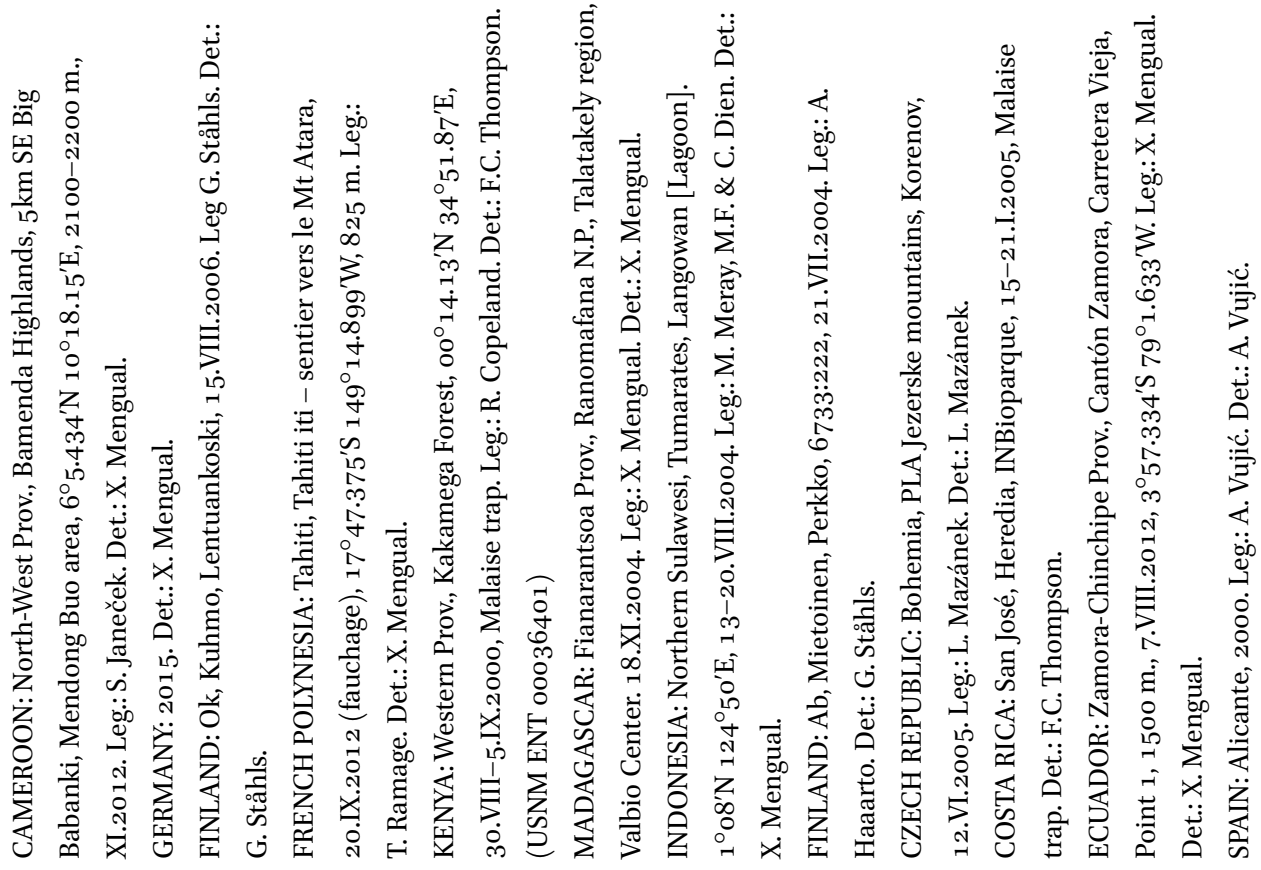

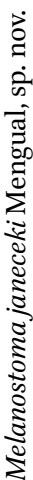
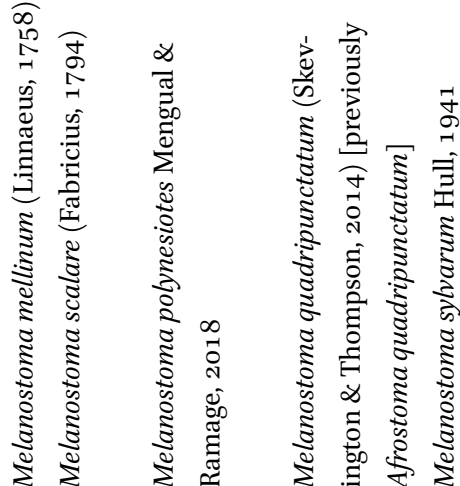

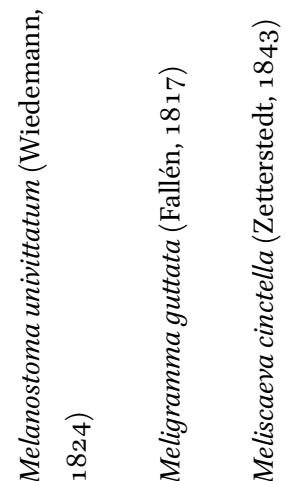
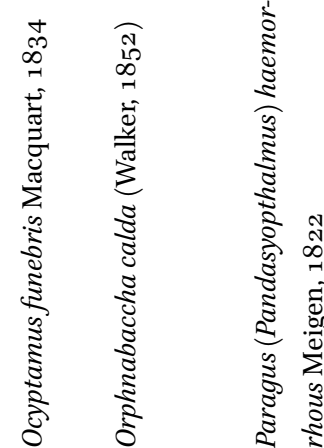


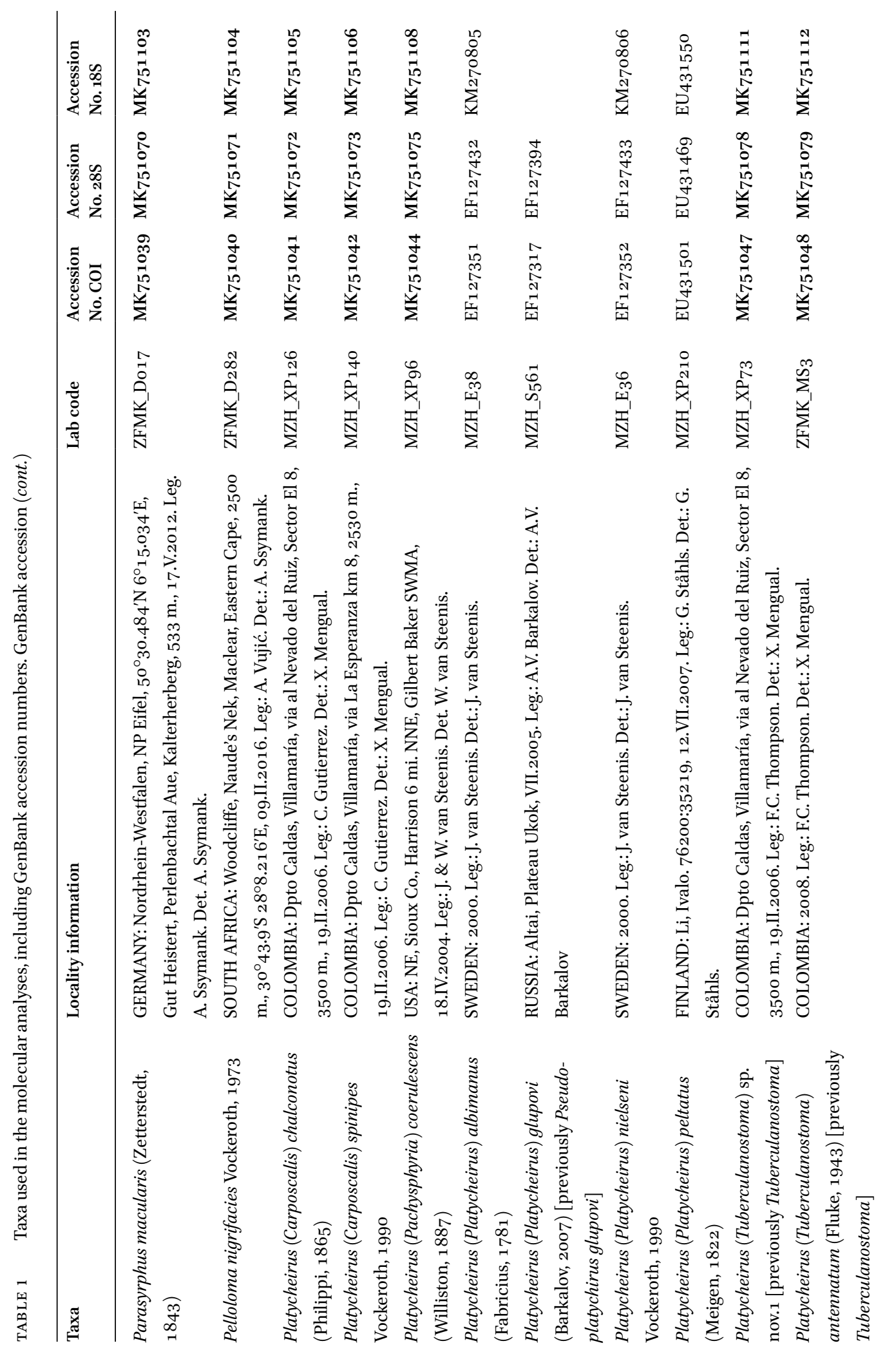




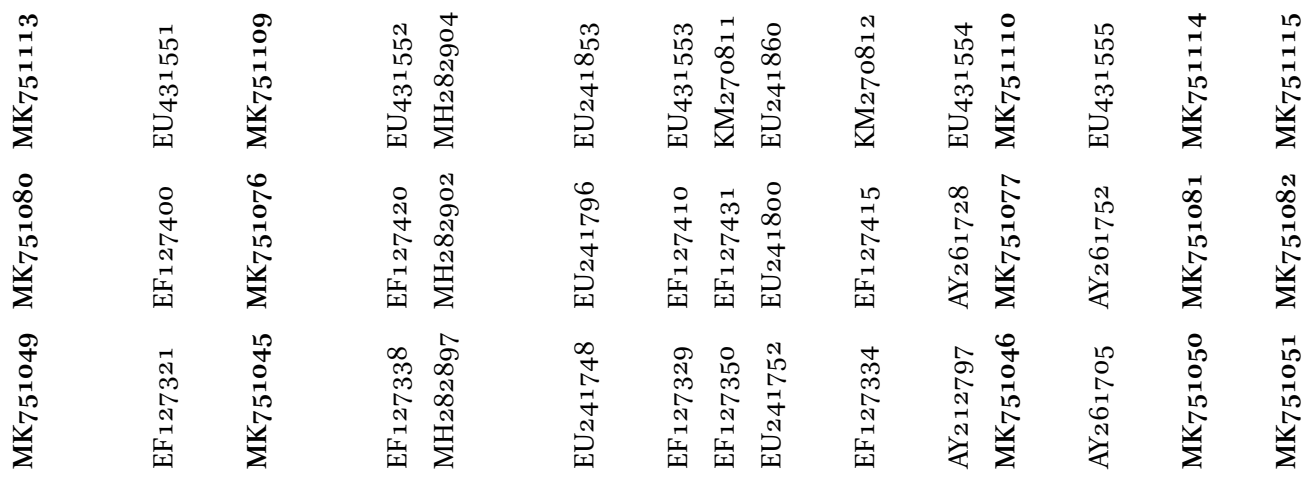

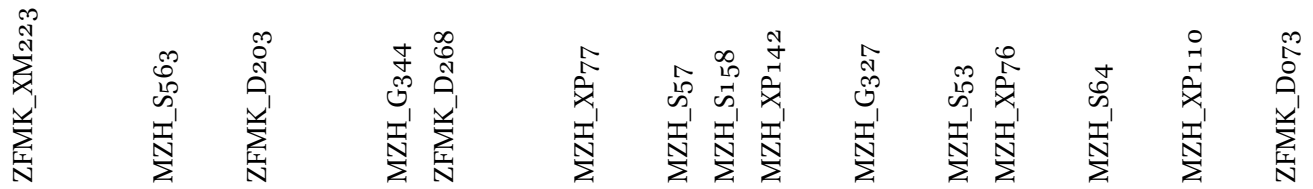

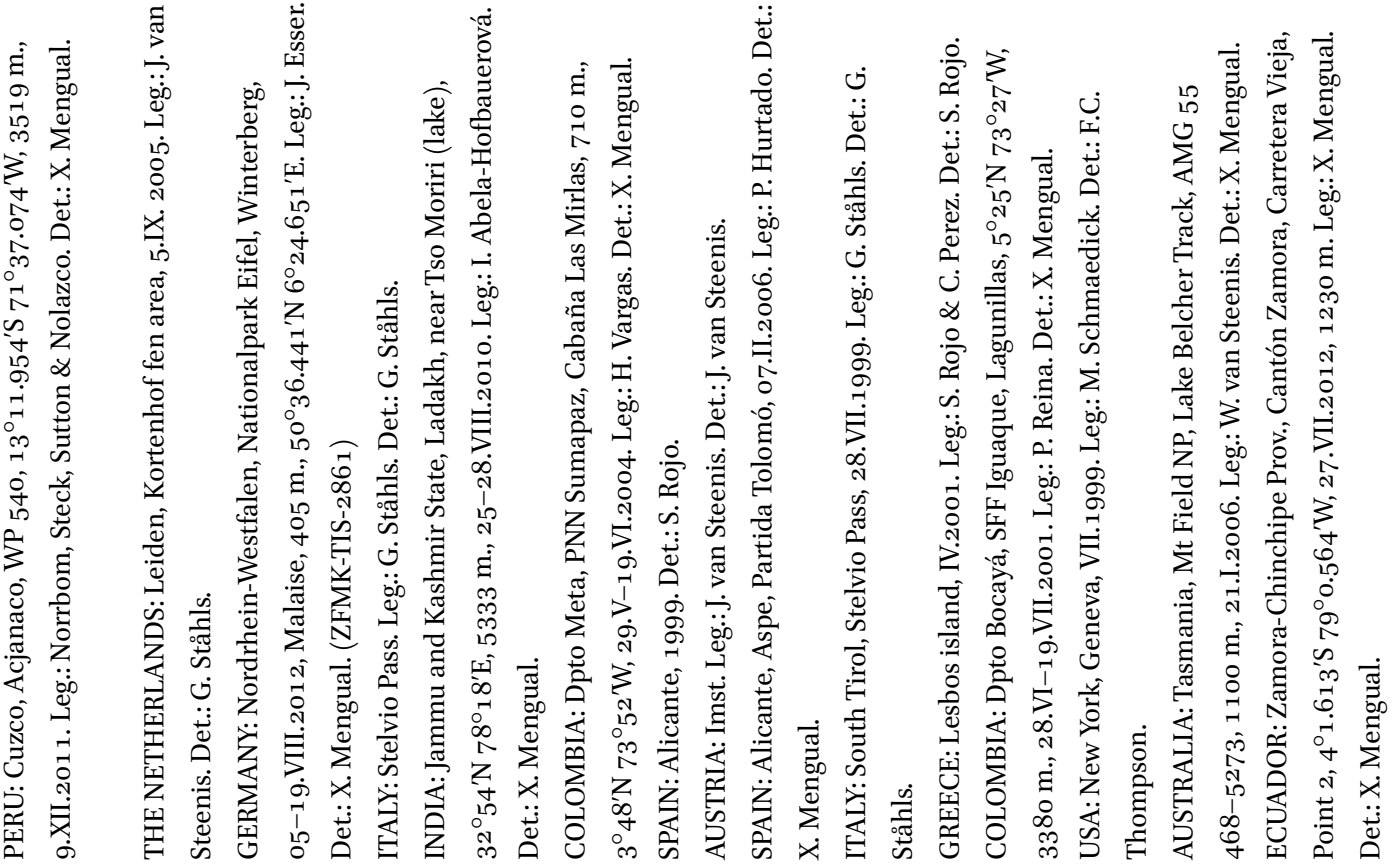

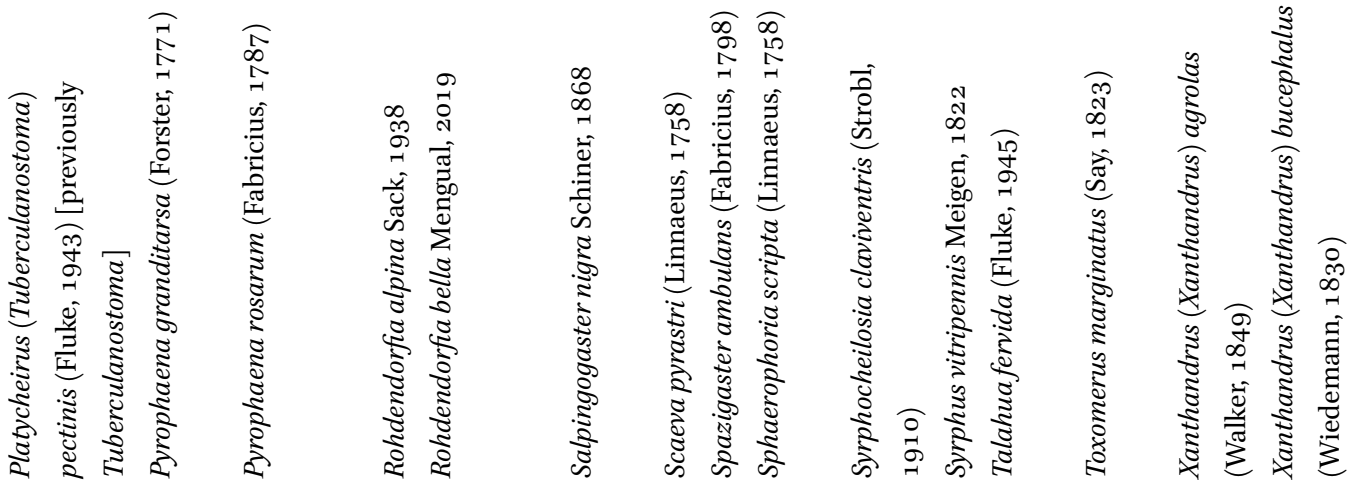




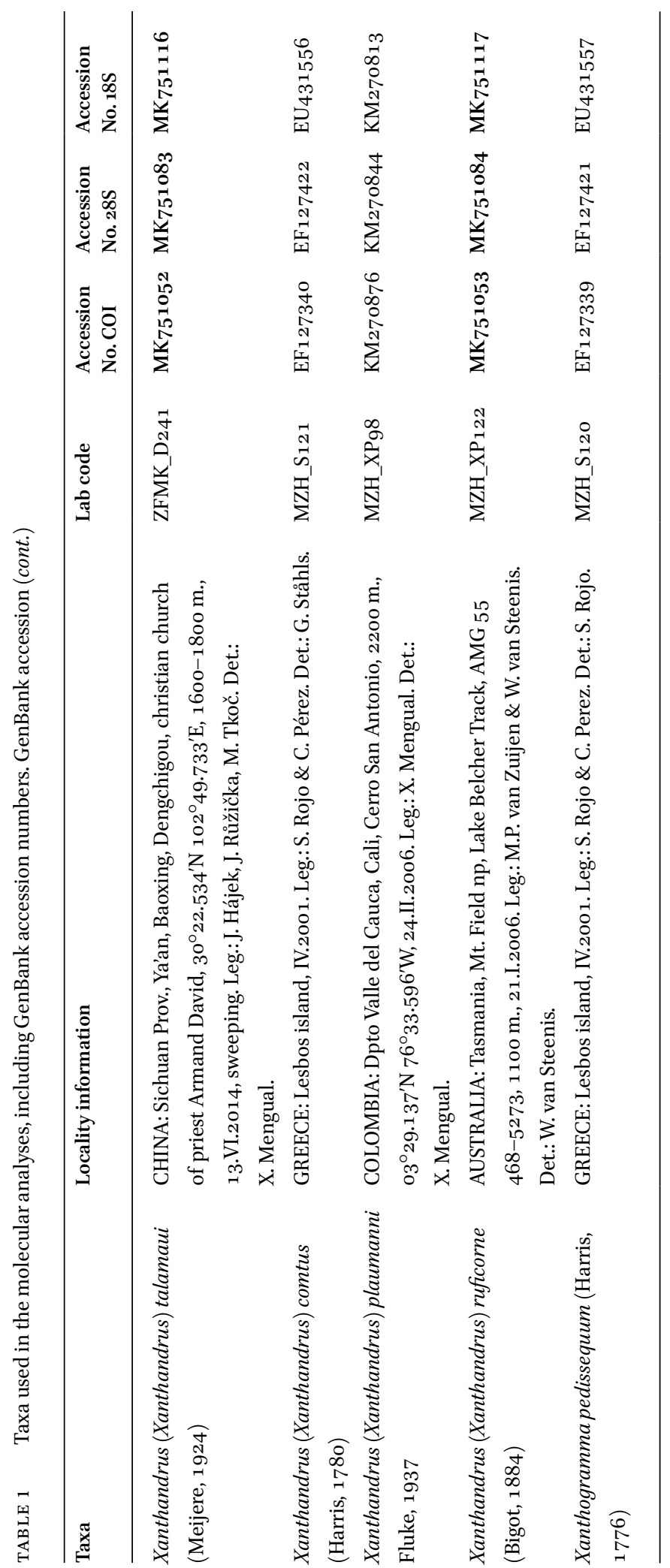




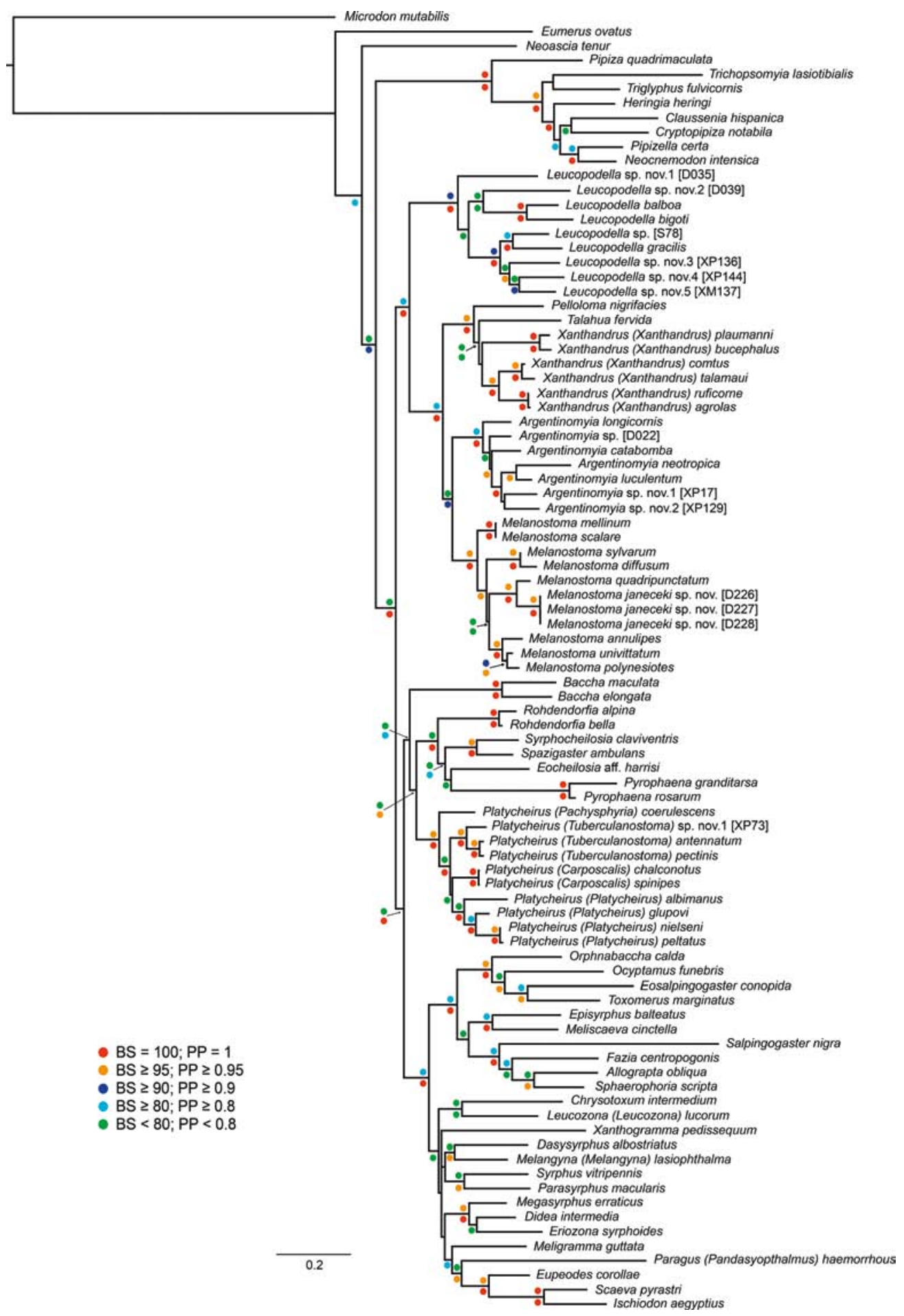

FIGURE 2 Maximum-likelihood tree based on the combined dataset (COI, 28S, and 18S) using Garli v.2.1.17 and the structural alignment for $28 \mathrm{~S}$ and $18 \mathrm{~S}$. Bootstrap support values (above) and Bayesian posterior probabilities (below) are depicted at the nodes (only $>50$ or $>0.5$, respectively). BS = Bootstrap support values; $\mathrm{PP}=$ Bayesian posterior probabilities. 
group of (Eristalinae + (Pipizinae + Syrphinae)); the same argument is valid for the inclusion of all genera of Pipizini plus Eumerus ovatus Loew, 1848 and Neoascia tenur (Harris, 1780). Members of Bacchini and Melanostomini were resolved as sister taxa of the other tribes of Syrphinae in previous works. Thus, in order to have a general view of the subfamily Syrphinae and to avoid any bias in the results due to taxon sampling, several Syrphini genera were also included in the analysis (see table 1 ).

\section{DNA extraction and sequencing}

A large fragment of the mitochondrial cytochrome c oxidase subunit I (COI) gene, a fragment of the nuclear 18S rRNA gene (variable region $\mathrm{V}_{4}$ ), and the $\mathrm{D}_{2}-\mathrm{D}_{3}$ region of the nuclear $28 \mathrm{~S}$ rRNA gene were used to performed the analyses. One to three legs, the entire abdomen or the entire specimen, either dry pinned or ethanol preserved, were typically used for DNA extraction. Extractions were carried out using the NucleoSpin Tissue DNA Extraction kit (Machery-Nagel, Düren, Germany) following manufacturer's instructions; samples were resuspended in $100 \mu$ l ultra-pure water. Remnants of specimens were preserved and labelled as DNA voucher specimens and deposited at the Zoological Museum of the Finnish Museum of Natural History [MZH] and at the Zoological Museum Alexander Koenig [ZFMK], as listed in table 1.

DNA primers and PCR amplification protocols for mitochondrial COI, and nuclear $28 \mathrm{~S}$ and $18 \mathrm{~S}$ rRNA genes were the same as described in Mengual et al. (2008b, 2015) and RozoLopez \& Mengual (2015). Amplified DNA was electrophoresed on $1.5 \%$ agarose gels for visual inspection of amplified products. PCR products were enzymatically treated with ExoSap-IT (USB, Cleveland, oh, USA) or were cleaned using the commercially available QIAquick PCR Purification Kit (QIAgen ${ }^{\circledR}$ ). Bidirectional sequencing reactions were carried out by Macrogen $($ Inc. Chromatograms were edited for base-calling errors and assembled using Geneious 7.1.3 (Biomatters@ Ltd).

\section{Sequence alignment}

The alignment of the protein-coding COI gene was done manually and it was not necessary to include gaps in this alignment. A total of 1,128 nucleotide characters were obtained for the COI data matrix. The $18 \mathrm{~S}$ and $28 \mathrm{~S}$ rRNA genes were aligned using the secondary structure of these genes, as explained by Kjer (1995) and implemented in Mengual et al. (2012, 2015) and Mengual (2015). The aligned small fragment of $18 \mathrm{~S}$ used in this analysis had a total sequence length of $370 \mathrm{bp}$ including gaps (ranging from $35^{\circ} \mathrm{bp}$ to $35^{6} \mathrm{bp}$ without gaps), and the $\mathrm{D}_{2}-3$ region of $28 \mathrm{~S}$ a total of $658 \mathrm{bp}$ including gaps (ranging from $562 \mathrm{bp}$ to 589 bp without gaps). The final dataset had 2,156 bp.

\section{Barcoding analysis}

Thompson \& Skevington (2014) used DNA barcodes of the Bacchini sensu lato genera to place Afrostoma into phylogenetic context. Although the utility of a fragment of a single gene for phylogenetic inference is questionable (see Doyle, 1992; Nichols, 2001; Hebert \& Gregory, 2005, among others), the present author followed the analytical methodology used by Thompson \& Skevington (2014), explained in Skevington \& Thompson (2012), in order to incorporate the new species of Melanostoma without metasternal excavation to the same data matrix and to be able to compare the results of the barcoding analysis with the phylogenetic analysis based on three molecular markers. DNA sequences for the 5 ' end of the COI gene for the species analyzed by Thompson \& Skevington (2014) were downloaded from GenBank and three sequences from the new Melanostoma species from Cameroon were added to the matrix (658 bp of the $5^{\prime}$ end). 
Bayesian inference using the Markov Chain Monte Carlo algorithm as implemented in MrBayes 3.2.6 (Huelsenbeck \& Ronquist, 2001; Ronquist \& Huelsenbeck, 2003) was performed using a parallelized version of the software. Data were not divided into partitions following Thompson \& Skevington (2014). The best model of evolution for the data was determined using jModelTest 2.1.5 (Darriba et al., 2012) under the Akaike Information Criterion (AIC). The model chosen was GTR $+\mathrm{I}+\mathrm{G}$. Four chains (three hot, one cold) were run simultaneously for 500,000 generations, which were sufficient to bring the convergence (average standard deviation) to a value $<0.009$ (Ronquist et al., 2005). Trees were sampled every 100 generations, the temperature was set to 0.2 and the number of runs to 6 . The initial 1,250 trees $(25 \%)$ were discarded as burn-in and Bayesian posterior probabilities (PP) were calculated using a 50\% majority-rule consensus tree inferred from the data (fig. 1).

\section{Phylogenetic analyses}

The Maximum Likelihood analysis and the Bayesian inference were performed two times each, one without the COI barcode sequence of Afrostoma quadripunctatum Skevington \& Thompson, 2014, and a second time with the inclusion of this short sequence $(647 \mathrm{bp})$ to evaluate the phylogenetic position of this species even with only a partial sequence of one of the three sequenced genes. For the analytical runs the data set was divided in five partitions: first codon position of COI, second codon position of COI, third codon position of COI, $28 \mathrm{~S}$ gene and $18 \mathrm{~S}$ gene. The best evolutionary model that fit the data was chosen each partition using jModelTest 2.1.5 (Darriba et al., 2012) under the Akaike Information Criterion (AIC), as recommended by Posada and Buckley (2004). The model chosen for position 1 of COI was $\mathrm{GTR}+\mathrm{I}+\mathrm{G}$, TIM $1+\mathrm{I}+\mathrm{G}$ for position 2 and $\mathrm{TIM}_{3}+\mathrm{I}+\mathrm{G}$ for position 3 . The model GTR $+\mathrm{I}+\mathrm{G}$ was selected for $28 \mathrm{~S}$ and the preferred model for $18 \mathrm{~S}$ was $\mathrm{TVM}+\mathrm{I}+\mathrm{G}$. The inclusion of the COI sequence of Afrostoma quadripunctatum did not change the model selection.

Data was analyzed under the recommended models using Garli v.2.1.17 (Zwickl, 2006, 2011) under Maximum Likelihood (ML) criterion. The author conducted 24 independent runs using scorethreshforterm $=0.05$ and significanttopochange $=0.0001$ settings and the automated stopping criterion, terminating the search when the ln score remained constant for 50,000 consecutive generations. The tree with the highest likelihood was retained and is presented here (fig. 2). Bootstrap support values (BS) were estimated from 500 replicates using the same independent models in Garli.

Bayesian inference (BI) using the Markov Chain Monte Carlo algorithm as implemented in MrBayes 3.2.6 (Huelsenbeck \& Ronquist, 2001; Ronquist \& Huelsenbeck, 2003) was performed using a parallelized version of the software. Data were divided into the above five partitions and a separate $\mathrm{GTR}+\mathrm{I}+\mathrm{G}$ model for each partition was specified in the analysis where each partition has its own set of parameters. Priors were applied with default values. Six runs, with four chains each (one "cold" chain and three heated chains; temp $=0.2$ ), were performed simultaneously for 20,000,000 generations, which were sufficient to bring the convergence (average standard deviation) to a value $<0.007$ (Ronquist et al., 2005), sampling trees every 2,500 generations. The program Tracer 1.7.1 (Rambaut et al., 2018) was used to check convergence and acceptable mixing. The initial 2,00o trees (25\%) were discarded as burn-in and Bayesian posterior probabilities (PP) were calculated using a $50 \%$ majority-rule consensus tree inferred from the data (fig. 2).

Maximum Likelihood analysis and Bayesian inference were performed on the CIPRES Downloaded f Pom Brill. com०4/26/2023 09:04:30AM 
Science Gateway (Miller et al., 2010). All trees were drawn with the aid of FigTree v.1.4.4 (Rambaut, 2018), Adobe Illustrator and Adobe Photoshop ${ }^{\circledR} \mathrm{CS}_{5}$.

\section{Results}

\section{Barcoding analysis}

The Bayesian phylogram (fig. 1) based only on the DNA barcode region (the $5^{\prime}$ end of the COI gene) compares favorably with the cladogram from Thompson \& Skevington (2014, figure 2). The same groupings and the same inferred relationships were found in the present analysis with a minor nomenclatural change: Platycheirus concinnus (Snow, 1895) appears as Platycheirus pictipes (Bigot, 1884) following the synonymy proposed by Young et al. (2016b). The novelty in the present study is the placement of the new species without metasternal excavation, Melanostoma janeceki sp. nov., as sister-group of Afrostoma quadripunctatum [= Melanostoma quadripunctatum comb. nov. in fig. 1] with the highest Bayesian posterior probability. Note that Afrostoma quadripunctatum appears as Afrostoma vockerothi in the figure 2 of Thompson \& Skevington (2014), and hereafter this species is referred as Afrostoma quadripunctatum or as Melanostoma quadripunctatum comb. nov. The group (Melanostoma janeceki sp. nov. + Afrostoma quadripunctatum) has a PP of 1, and the barcode similarity based on uncorrected pairwise distance between Melanostoma janeceki sp. nov. and Afrostoma quadripunctatum is $96.136 \%$ with the D226 and D228 specimens (25 nucleotide differences) and $96.059 \%$ with the D227 specimen (26 nucleotide differences).

The DNA barcodes for the three specimens of Melanostoma janeceki sp. nov. were almost identical. The only difference among the sequences of Melanostoma janeceki sp. nov. was an ambiguous call in one base (W for specimen D227 and A for specimens D226 and D228).

\section{Phylogenetic analyses}

No topological differences were found when Afrostoma quadripunctatum [= Melanostoma quadripunctatum comb. nov. in fig. 2] was excluded from the analysis, and the same relationships among taxa were recovered with both dataset, with or without the DNA barcode sequence of Afrostoma quadripunctatum. The ML and BI analyses resulted in highly similar tree topologies and are summarized together. The ML tree including the Afrostoma barcode with the best likelihood score $(-28846.913085)$ is presented in fig. 2 with the PP from the Bayesian analysis and the BS values from the ML analysis.

Although the taxonomic sampling effort was done to include all the diversity of the Bacchini sensu lato, it is worth to mention the other syrphine genera and pipizines were resolved in agreement with previous studies (Mengual et al., 2008a, 2012, 2015; Mengual, 2015; Young et al., 2016a; Mengual et al., 2018), with members of Pipizinae resolved as sister-group of Syrphinae. The subfamily Syrphinae was resolved monophyletic with genera grouped into three major clades. The first major clade comprises all the Syrphini genera, including the representatives of Toxomerini and Paragini. The second major clade comprises the genera Leucopodella Hull, 1949, Pelloloma Vockeroth, 1973, Talahua Fluke, 1945, Xanthandrus Verrall, 1901, Argentinomyia Lynch Arribalzaga, 1891, Afrostoma and Melanostoma. In this clade, Leucopodella species were placed as sister-group of two smaller clades: (Pelloloma + (Talahua + Xanthandrus)) and (Argentinomyia + Melanostoma), including Afrostoma. It is important to point out that the two studied species without metasternal excavation, i.e., Melanostoma janeceki sp. nov. and Afrostoma quadripunctatum, were resolved as sister taxa and Downloaded from Brill. como4/26/2023 09:04:30AM 
embedded among the species of the genus Melanostoma, which all have an excavation in the metasternum.

The third major clade as resolved in the present study has the representatives of the Bacchini, with Baccha, Platycheirus and all the other genera related to Platycheirus, i.e., Tuberculanostoma, Pyrophaena, Syrphocheilosia Stackelberg, 1964, Spazigaster Rondani, 1843, and Rohdendorfia Smirnov, 1924. Within this clade, Baccha was resolved as the sistergroup of the other genera, Tuberculanostoma was placed embedded in the Platycheirus radiation, and (Pyrophaena + (Rohdendorfia + $($ Syrphocheilosia + Spazigaster))) were resolved as a clade sister to Platycheirus, including Tuberculanostoma.

\section{Melanostoma janeceki Mengual, sp. nov.}

Melanostoma sp. in Vlašánková et al. (2017).

Figs. 3, 5C-E.

Differential diagnosis. Black, straight face with small, round facial tubercle; black thorax and abdomen black with terga $3-5$ with two lateral, small yellow maculae on anterior margin (fig. 3). This species of Melanostoma with a complete metasternum (fig. ${ }_{5} \mathrm{C}, \mathrm{D}$ ) is only known from Cameroon, and it is very similar to Melanostoma quadripunctatum (Skevington \& Thompson, 2014) comb. nov., known from Kenya and Uganda (fig. 5A, B). They differ by the COI gene sequence, sterna coloration in females (entirely yellow in $M$.janeceki sp. nov.; entirely black with two lateral yellow maculae on anterior margin of terga $2-5$ in M. quadripunctatum; fig. $5_{\mathrm{E}, \mathrm{F})}$ and by the leg coloration: $M$. janeceki sp. nov. has pro- and mesofemora yellow in both sexes, and metafemora black except yellow on basal $1 / 4-1 / 3$ in males or metafemora entirely yellow in females (fig. 3); and M. quadripunctatum males and females have all femora black with the very apex pale (fig. $5^{\mathrm{A}}$ ).
Type locality. Cameroon: Northwest Province, Bamenda Highlands, ca. $5 \mathrm{~km}$ southeast of Big Babanki, Mendong Buo area, $6.592699^{\circ} \mathrm{N}, 10.189999^{\circ} \mathrm{E}, 2100-2200 \mathrm{~m}$.

\section{Description}

Male: Head: Face straight with distinct facial tubercle, entirely black, pale pilose, sparsely grey pruinose except tubercle shiny; lunule black, shiny; frontal triangle black, sparsely grey pruinose, brownish pilose; eye contiguity long, longer than vertical triangle; ocellar triangle dark pilose; antenna brown, basoflagellomere darker apically; arista pilose, with pile shorter than the arista width at base; occiput black, silver grey pruinose, white pilose on ventral 1/2, brownish pilose on dorsal 1/2.

Thorax: Black except postalar callus slightly paler, brownish black; scutum shiny black, sparsely brownish pruinose, with short and long yellow pile with some darker pile; postpronotum white/grey pruinose, bare; scutellum black, yellow pilose with some darker pile intermixed, subscutellar fringe long, yellow. Pleuron black, pale pilose, sparsely pale pruinose; calypter yellow, yellow pilose; plumula yellow; halter pedicel and capitulum yellow; posterior spiracular fringes yellow; metasternum complete, bare. Scutum and pleuron with a golden iridescence. Wing: brownish, entirely microtrichose; alula broader than costal cell. Legs: pro- and mesofemora brown; pro- and mesotrochanter yellow; pro-and mesofemora yellow; pro- and mesotibia yellow with a medial black annulus; protarsi dark, probasitarsomere yellow basally; apical three mesotarsomeres black, basal two mesotarsomeres yellow; metacoxa black and metatrochanter yellow; metafemur black with basal 1/4-1/3 yellow and femoral-tibial joints yellow; metatibia black with basal 1/4-1/3 yellow; metatarsi black.

Abdomen: Parallel-sided, without lateral margin, entirely black except for the two lateral, small yellow maculae on anterior margin of 

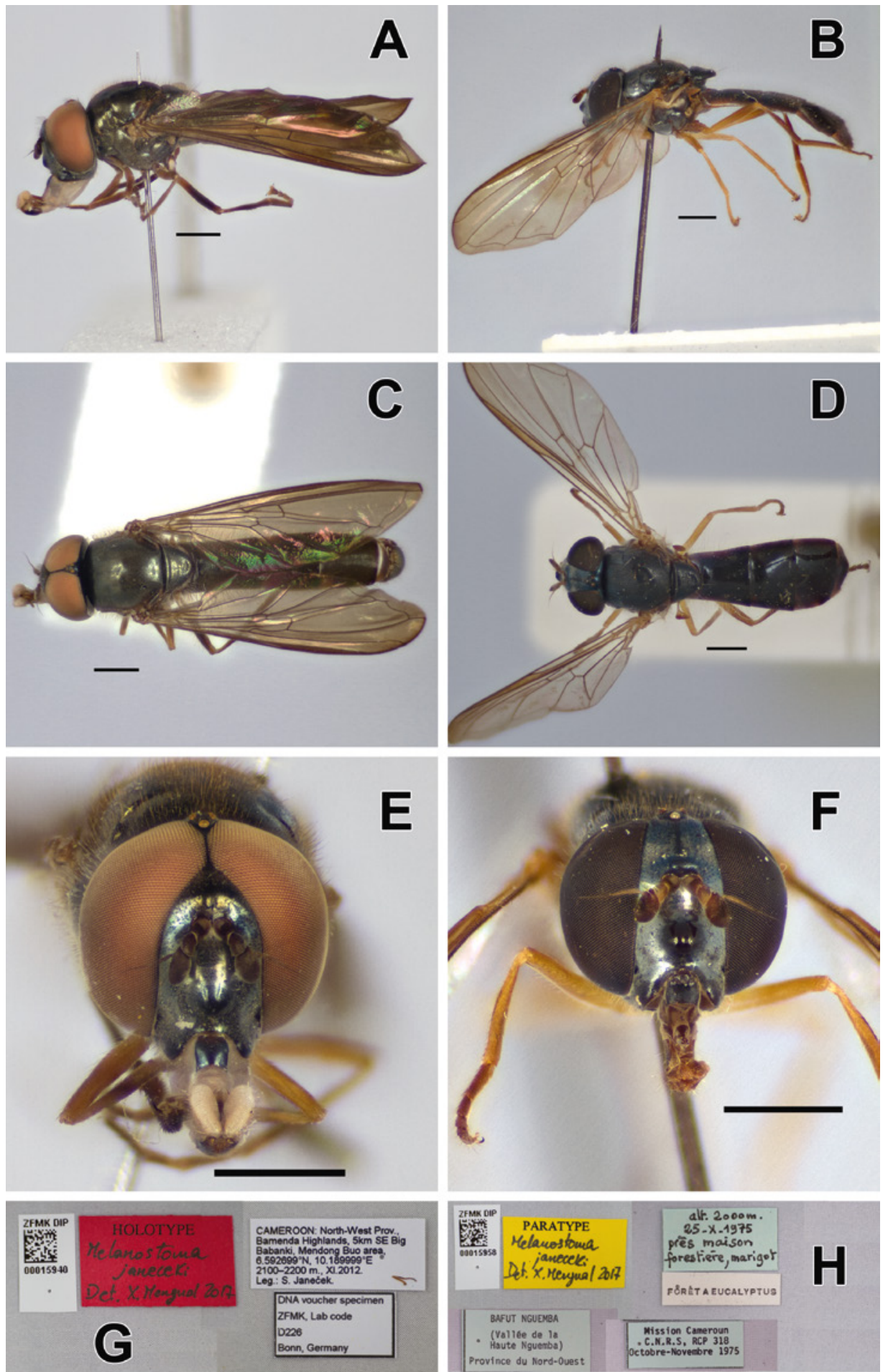

FIGURE 3 Melanostoma janeceki Mengual, sp. nov. A, male holotype (ZFMK-DIP-ooo15940), lateral view; B, female paratype (ZFMK-DIP-ooo15958), lateral view; C, male holotype, habitus; D, female paratype (ZFMK-DIP-ooo15958), habitus; E, male holotype, frontal view; F, female paratype (ZFMKDIP-ooo15958), frontal view; G, male holotype, labels; H, female paratype (ZFMK-DIP-ooo15958), labels. 

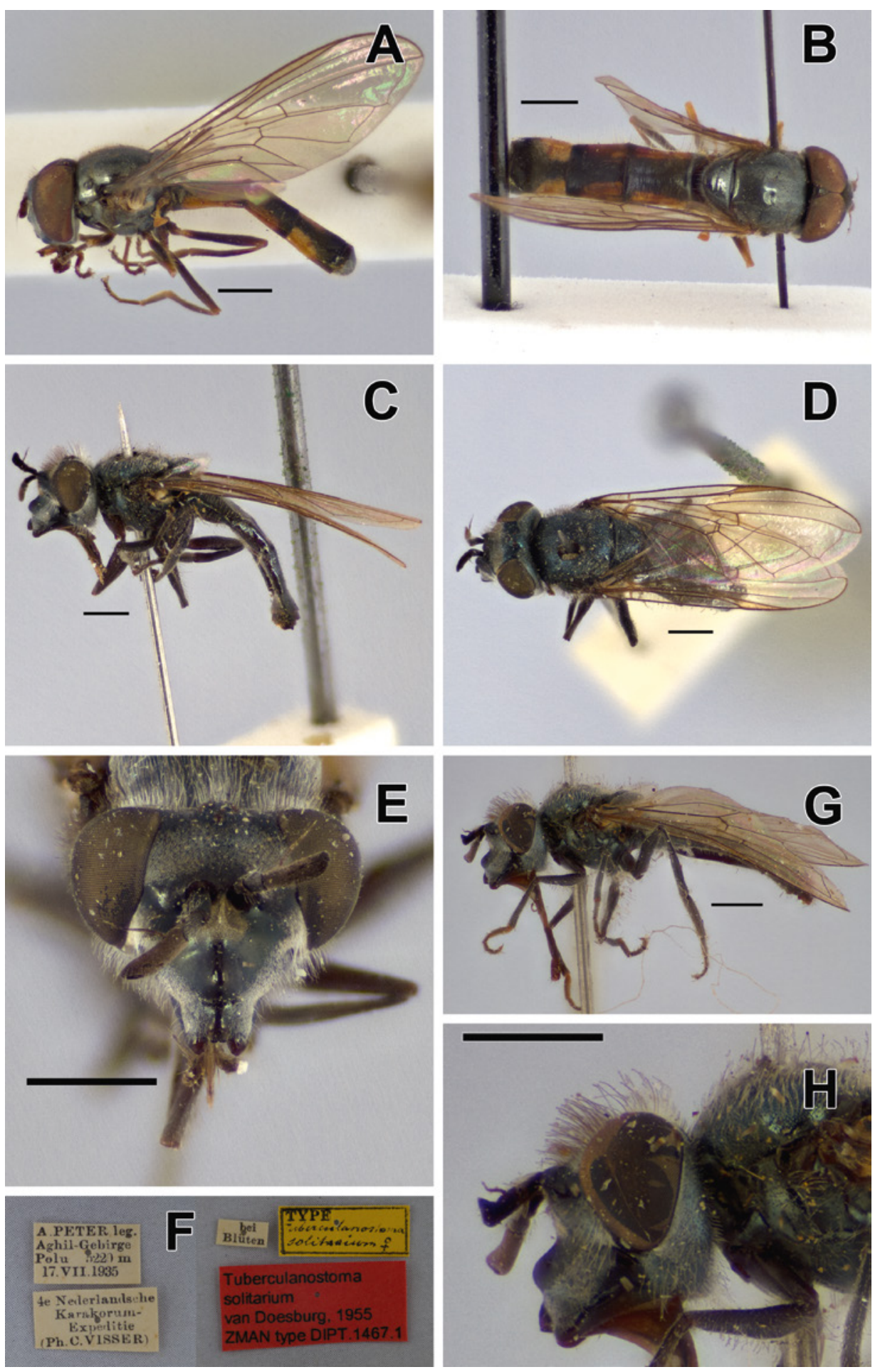

FIGURE 4 A-B: Melanostoma sp. from Cameroon (ZFMK-DIP-ooo15959) with complete metasternum. A, lateral view; B, habitus. C-H: Platycheirus solitarius (van Doesburg, 1955) comb. nov. C, female holotype, lateral view; D, female holotype, habitus; E, female holotype, frontal view; F, female holotype, labels; G, female paratype, lateral view; $\mathrm{H}$, female paratype, head, lateral view. 

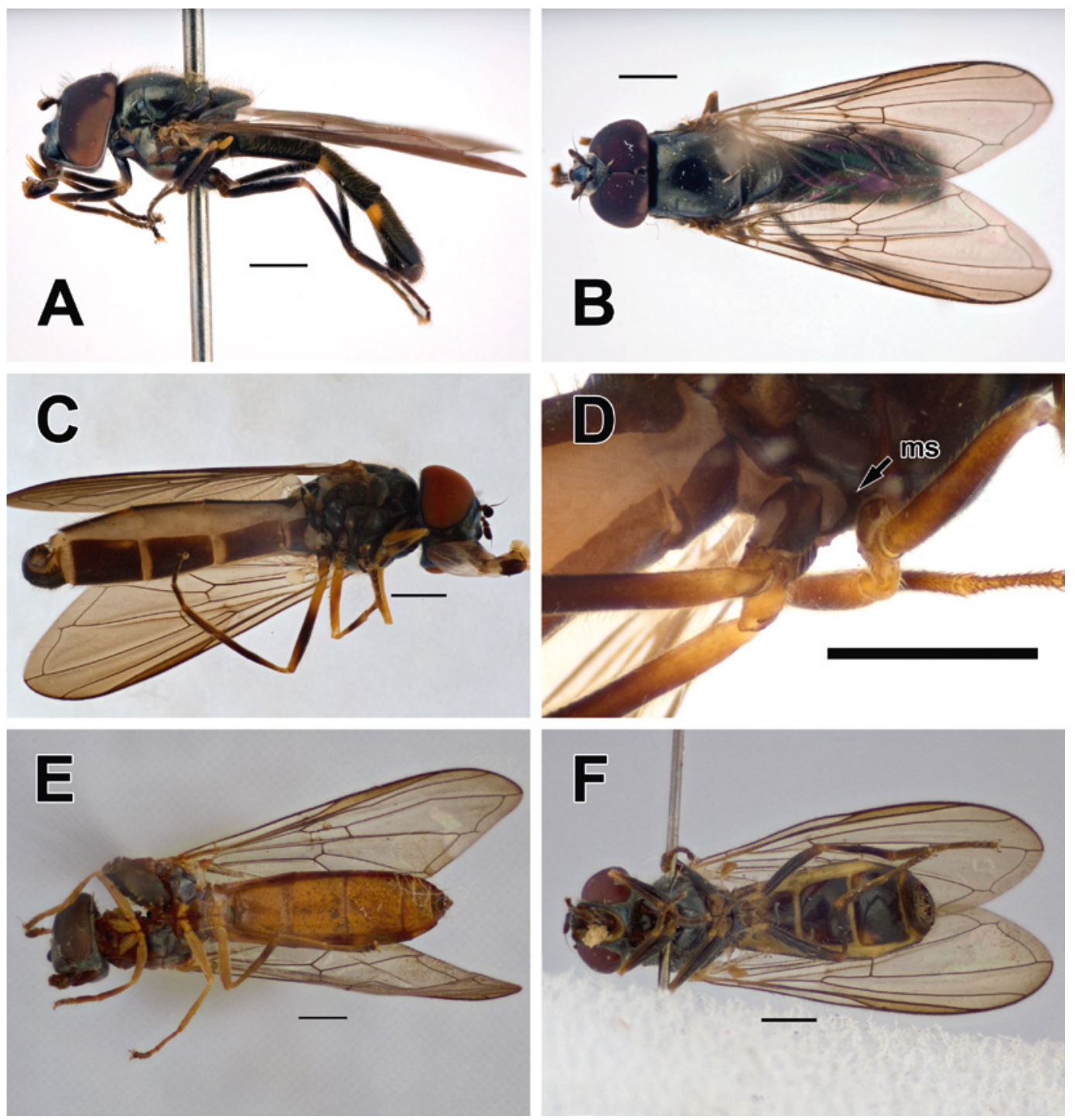

FIgURE 5 A-B: Melanostoma quadripunctatum (Skevington \& Thompson, 2014) comb. nov., male holotype. A, lateral view; B, habitus. C, Melanostoma janeceki Mengual, sp. nov., male holotype, ventral view. D, Melanostoma janeceki Mengual, sp. nov., male paratype (ZFMK-DIP-00015941), detail of metasternum (ms). E, Melanostoma janeceki Mengual, sp. nov., female paratype (ZFMK-DIP-00015957), ventral view. F, Melanostoma quadripunctatum, female (ZFMK-DIP-00015952), ventral view.

terga $3^{-4}$; tergum 5 has also two lateral, small yellow maculae but less evident. Terga dull black pruinose, with long yellow pile laterally and short black pile medially; sterna black except sterna $3^{-4}$ with a yellow fascia on posterior margin and sternum 5 with two lateral yellow maculae. Male genitalia: very similar to male genitalia of $M$. quadripunctatum (Thompson \& Skevington, 2014, figure 3).

Female: Similar to male except for normal sexual dimorphism and as follows: frons black with two lateral silver pruinose maculae on eye margin; pro- and mesolegs yellow except apical tarsomeres; metafemur yellow; terga 
2-5 black with two lateral yellow maculae (those on tergum 2 elongated along lateral margin); sterna yellow.

Variation: No variation has been observed in the studied specimens, although some variability in the extension of the abdominal maculae and in the coloration of the legs at some extent might be possible.

Length $(\mathrm{N}=3)$ : Body, 9.17 mm (8.3-10.2 mm); wing, 7.9 $\mathrm{mm}(7.2-8.6 \mathrm{~mm})$.

Geographical distribution. Species known from Cameroon.

Etymology. The new species is named after its collector, Dr. Štěpán Janeček. Species epithet to be treated as a noun in the genitive case.

Biology. See Vlašánková et al.(2017, as Melanostoma sp.) for its relationship with Impatiens burtonii var. burtonii Hook. f. (Balsaminaceae).

Material examined: Type material. Holotype, male, pinned with genitalia in microvial, deposited in the Zoologisches Forschungsmuseum Alexander Koenig (ZFMK), Bonn, Germany, and labelled: "CAMEROON: NorthWest Prov., // Bamenda Highlands, $5 \mathrm{~km}$ SE Big // Babanki, Mendong Buo area, // 6.592699 ${ }^{\circ} \mathrm{N}$, 10.189999 ${ }^{\circ}$ / / 2100-2200 m., XI.2012. // Leg.: S. Janeček." "DNA voucher specimen // ZFMK, Lab code // D226 // Bonn, Germany" "HOLOTYPE // Melanostoma // janeceki // Det. X. Mengual 2017" [red] "ZFMK DIP o0015940" [barcode]. Paratypes: 10", same data as holotype, DNA voucher ZFMK-D227 [ZFMK; ZFMK-DIP-00015941]; 19, same data as holotype, DNA voucher ZFMK-D228 [ZFMK; ZFMK-DIP-oo015942]; 10', CAMEROON: North-West Prov., Mezan Division, BafutNgemba Forest Reserve (35 km from Bamenda), in the way to the Lake (env. Chemin du Lac), 1500 m., 12.X.1970, L. Matile [ZFMK;
ZFMK-DIP-00015955];10', CAMEROON:NorthWest Prov., Mezan Division, Bafut-Ngemba, env. Maison Forest, 2000 m., 10.x.1970, L. Matile [MNHN; ZFMK-DIP-ooo15954]; 10", CAMEROON: North-West Prov., Mezan Division, Bafut-Ngemba, Vallée de la Haute Ngemba, 2100 m., 27.X.1975, Mission Cameroun C.N.R.S. RCP 318 [MNHN; ZFMK-DIP-00015956]; 1우, CAMEROON: North-West Prov., Mezan Division, Bafut-Ngemba, Vallée de la Haute Ngemba, galerie, marigot avaut lac, 1800-1900 m., 30.x.1975, Mission Cameroun C.N.R.S. RCP 318 [MNHN; ZFMK-DIP-ooo15957]; 19, CAMEROON: North-West Prov., Mezan Division, Bafut-Ngemba, Vallée de la Haute Ngemba, prés Maison forestiére, marigot, 2000 m., 25.X.1975, Mission Cameroun C.N.R.S. RCP 318 [ZFMK; ZFMK-DIP-0oo15957].

Material of Melanostoma quadripunctatum (Skevington \& Thompson, 2014) comb. nov. KENYA: Kakamega Forest, $1585 \mathrm{~m}$. [ $=5200$ ft.], 18.xii.1970, E.E. Stubbs [40' 2\%, BMNH; $20^{7}$ 1ㅇ, ZFMK; ZFMK-DIP-00019927, ...00015944, ...00015945,...00015947,...00015950,...00015951, ...00015943, ...00015946, ...00015952]; ..., 19.xii. 1970, ... [1우 BMNH; ZFMK-DIP-ooo15953]; ..., 20.xii.1970,... [20', BMNH;ZFMK-DIP-ooo15948, ...00015949].

Remarks. Prior to this study, female specimens of $M$. quadripunctatum were unknown. They are very similar to females of $M$.janeceki sp. nov., but they can be distinguished by sternal and leg coloration as indicated in the diagnosis (fig. $5^{\mathrm{F}}$ ).

\section{Discussion}

\section{Inferred generic relationships}

Pelloloma, Talahua, Tuberculanostoma and Eocheilosia have been included in a multi-gene phylogenetic analysis for the first time (see fig. 2). In its original description, Vockeroth (1973) placed the genus Pelloloma within the 
Syrphini, but already mentioned the possibility that it could be placed among the Melanostomini. Kassebeer (2000a) explained using morphological characters the reason to move Pelloloma to Melanostomini. Present results (fig. 2) support the placement of this genus in the Melanostomini.

Fluke (1945) described a new Melanostoma subgenus, Melanostoma (Talahua), for the species Melanostoma fervidum Fluke, 1945, which is characterized by large male genitalia. Hull (1949) followed Fluke (1945) and considered Talahua as a Melanostoma subgenus, but Thompson et al. (1976) elevated Talahua to full generic status as it has a complete metasternum, not reduced as defined for Melanostoma. More recently, Thompson (1999) placed a second species in the genus Talahua, Melanostoma palliatum Fluke, 1975, which has normal-sized male genitalia. Hereafter, the size of the male genitalia was not diagnostic for Talahua, but only the character of metacoxa with a pile tuft postero-medially as stated in the identification key by Thompson (1999). Our analysis resolved Talahua and Xanthandrus as sister taxa and Argentinomyia as sister taxon of Melanostoma (fig. 2), supporting the decision of Thompson et al. (1976).

When Fluke (1943) described his new genus Tuberculanostoma from Ecuador, he stated the similarity with Carposcalis Enderlein, 1938 (at the time most Carposcalis species were treated as Melanostoma) based on the presence of curved bristles on the profemur. This similarity was also pointed out by Hull (1949). Fluke (1943) also mentioned some diagnostic characters, such as face produced forward into a snout and a prominent facial tubercle, and the preferential habitat in high elevations. Years later, van Doesburg (1955) described Tuberculanostoma solitarium van Doesburg, 1955 from the Karakorum Mountains (a mountain range spanning the borders of Pakistan, India, and China) (see fig. ${ }_{4} \mathrm{C}-\mathrm{H}$ ). This species has a produced face and a clear facial tubercle, but there are many differences from the Neotropical Tuberculanostoma as stated by Thompson \& Skevington (2014). Results from Young et al. (2016b) using the 5 end of the COI gene resolved Tuberculanostoma embedded in Platycheirus, somehow related with the stegnus subgroup, referred as subgenus Platycheirus (Carposcalis) by other authors (see Vockeroth, 1990; Thompson \& Skevington, 2014; Young et al., 2016b). Previously, Vockeroth (1990) suggested the possibility to include Tuberculanostoma in Platycheirus as an alternative placement. Present results (fig. 2) support the suggestion of Vockeroth (1990) and corroborate the results of Young et al. (2016b). Based on the current evidences, the genus Platycheirus comprises four subgenera: Platycheirus (Carposcalis), Platycheirus (Pachysphyria), Platycheirus (Platycheirus), and Platycheirus (Tuberculanostoma) comb. nov. Nevertheless, as stated by Young et al. (2016b), there is the possibility that other monophyletic species groups within the genus Platycheirus could be recognized as distinct in the future. The present results differ from the proposed subgeneric classification of Thompson \& Skevington (2014) as Pyrophaena and Eocheilosia are supported as valid genera and Pseudoplatychirus is recognized as a junior synonym of Platycheirus (new synonym). Platycheirus (Pachysphyria) is equivalent to the Platycheirus ambiguus species group sensu Vockeroth (1990), Nielsen (2004, 2014) and Young et al. (2016b). Based on molecular characters (Mengual et al., 2008; this study) and the morphological characters of the original descriptions, the Pseudoplatychirus species are Platycheirus species with elongated antennae, dichoptic males, widened protarsi, profemur with long, strong, curly setae and projected face. Broadened protarsi, projected face and modified setae on the profemur are characteristics also found in other species groups within Platycheirus. All 
known specimens of Pseudoplatychirus were collected at high elevations (van Doesburg, 1955; Zimina, 1958; Barkalov, 2007).

The present author has studied the holotype and paratype females of Tuberculanostoma solitarium deposited at NBC (fig. $4 \mathrm{C}-\mathrm{H}$ ) together with several Neotropical Tuberculanostoma species, and a few morphological differences are clear: frons broader than eye width in frontal view (much narrower than eye width in frontal view for the Neotropical species), frons and vertex with very long, erected pile (much shorter in Neotropical species), dorsal occiput without long, black bristles (dorsal occiput with $15^{-20}$ long, black bristles in Neotropical species), face with a patch of long pile on parafacia (Neotropical species without such pile patch), deep antero-apical tentorial pit in the inner side of the basoflagellomere (absence of tentorial pits in Neotropical species), procoxa medially broadened laterally (procoxa without modifications in Neotropical species), scutellum without bristles (scutellum with 1, usually 2 pairs of long, black bristles on posterior margin in Neotropical species), femora with dense, long pile postero-ventrally (femora with scattered pile in Neotropical species), wing marginal fringe short (wing marginal fringe longer in Neotropical species). The author of the present paper finds some morphological similarity between Tuberculanostoma solitarium and the species of Pseudoplatychirus such as projected face, somehow reduced eyes, and enlarged gena and ventral occiput. The two known species of Pseudoplatychirus resemble extremely morphologically modified species of the Platycheirus manicatus species group (see Nielsen \& Barkalov, 2017). In the $P$. manicatus species group both sexes have the face slightly to strongly protruding below as in Pseudoplatychirus, and males of the P. manicatus species group are characterized by the two basal broadened tarsomeres of the proleg, a character also present in the Pseudoplatychirus males. Unfortunately, only females of Tuberculanostoma solitarium are known and this sex does not have the mentioned broadened tarsomeres of the proleg. Either related to Platycheirus species with produced face or not, the species Platycheirus solitarius (van Doesburg, 1955) comb. nov. does not belong to Platycheirus (Tubeculanostoma) based on the morphological differences, and the shared morphological characters (produced face) might possibly be the result of adaptation to extreme conditions, in this case, very high elevations in the Andes and in the Karakorum Mountains. Perhaps, the only two known females of Platycheirus solitarius (collected conspecifically with the type series of Pseudoplatychirus peteri van Doesburg, 1955) belong to the same Platycheirus species group as the two species described as Pseudoplatychirus.

Hull (1949) described Eocheilosia as a subgenus of Cheilosia Meigen, 1822 (Eristalinae, Rhingiini) for the species Cheilosia ronana Miller, 1921. Thompson (1972) placed his new species Platycheirus milleri Thompson, 1972 [now known as Eocheilosia huttoni (Thompson in Thompson \& Vockeroth, 1989)] in Platycheirus, although he pointed out that this taxon may deserve generic recognition. Thompson \& Vockeroth (1989) and Thompson \& Skevington (2014) considered Eocheilosia as subgenus of Platycheirus, and Thompson (2008) stated that Eocheilosia is used for those species of Platycheirus with unmodified male prolegs present in New Zealand. Present study (fig. 2) resolved Eocheilosia within a clade of genera previously placed under Platycheirus (Thompson \& Rotheray, 1998), including Rohdendorfia, Syrphocheilosia, Spazigaster, and Pyrophaena. Previous DNA barcoding analyses (Thompson \& Skevington, 2014; Young et al., 2016b; van Steenis et al., 2019) based on the $5^{\prime}$ end of the COI gene also resolved Eocheilosia 
notata (Bigot, 1884) [as Platycheirus (Pseudoplatycheirus) notatus in Young et al. (2016b, figure 6)] within this clade. Hence, molecular evidence supports the full generic status for Eocheilosia comb. nov.

Although there were no specimens available for the present study, the generic status of Afroxanthandrus is worth to comment. Kassebeer (200ob) described Afroxanthandrus as a new genus including Xanthandrus congoensis Curran, 1938 and his new species, Afroxanthandrus longipilus Kassebeer, 200o. Whittington (2003) listed the genus in his assessment of the Afrotropical syrphid fauna, but Mengual et al. (2008a) overlooked this taxon and did not include it in their classification. Later, Thompson \& Skevington (2014) considered it as a subgenus of Xanthandrus, but did not officially propose it. Recently, Thompson (2019) considered Afroxanthandrus a junior synonym of Xanthandrus. The genus Xanthandrus sensu Thompson \& Skevington (2014) is found in all biogeographic regions (Borges \& Pamplona, 2002), with the typical subgenus present in the Neotropical, Nearctic, Palaearctic, Oriental and Australasian Regions, Afroxanthandrus found in the Afrotropical Region, and the subgenus Androsyrphus known only from Jamaica. The main differences between Afroxanthandrus and Xanthandrus are: head of the female swollen medially (flat in Xanthandrus), scutum entirely pruinose and granulate (shiny without granulation in Xanthandrus), femora slightly thickened (not so in Xanthandrus), and male genitalia. Xanthandrus species have one-lobe, digitiform or pointed surstyli and small postgonites squarish or triangular in shape (see Dušek \& Láska, 1967; Borges \& Pamplona, 2003). On the other hand, Afroxanthandrus congoensis has small surstyli laterally displaced and enlarged postgonites rectangular in shape, with a quite distinct aedeagus (Kassebeer, 200ob). Based on male genitalia characters, the present author tentatively considers Afroxanthandrus as a valid genus (table 2).

The other taxon not available for molecular work in the present study is also placed in Xanthandrus. Thompson (1981) erected a new subgenus, Xanthandrus (Androsyrphus), for a species with swollen metafemora and with ventral spines on meso- and metafemora from Jamaica. He agreed that some dipterists might give full generic rank to Androsyrphus, but he hesitated to do so in the Bacchini sensu lato based on a leg character as legs are very variable in this group. Further analysis of this taxon combining morphology and molecular markers might change Thompson's (1981) decision.

\section{New generic diagnosis for Melanostoma}

Generic concepts within Bacchini sensu lato have generally been difficult to define (Young et al., 2016b). Nowadays, there are published identification keys to sort out all the bacchine and melanostomine genera using morphological characters (Vockeroth \& Thompson, 1987; Thompson \& Rotheray, 1998; Thompson, 1999; Thompson et al., 2010; Láska et al., 2013; Thompson \& Skevington, 2014). The importance of the metasternum shape during the history of syrphidology has been significant. The confusion between Platycheirus and Melanostoma was frequent until Andersson (1970) found the differences in the shape of the metasternum. Since then, a largely reduced, spearhead-shaped metasternum is a diagnostic character for the genus Melanostoma and Platycheirus species have an entire metasternum. Although the molecular data were limited, the lack of the basolateral excavation in the metasternum was a diagnostic character for Thompson \& Skevington (2014) to erect a new genus, Afrostoma. Based on their own arguments, Afrostoma flies look very like Melanostoma species, endemic of the Afrotropical Region where the only other melanostomine is Melanostoma, with very similar 
TABLE 2 New synthesis of generic and subgeneric names of Bacchini stat. rev. and Melanostomini stat. rev. (Syrphidae: Syrphinae)

\begin{tabular}{|c|c|c|c|c|}
\hline Tribe & Genus & Subgenus & Author, year & Type species \\
\hline Melanostomini & Afroxanthandrus & & Kassebeer, 2000 & $\begin{array}{l}\text { Afroxanthandrus congoensis } \\
\text { (Curran, 1938) }\end{array}$ \\
\hline Melanostomini & Argentinomyia & & $\begin{array}{l}\text { Lynch Arribalzaga, } \\
1891\end{array}$ & $\begin{array}{l}\text { Argentinomyia testaceipes Lynch } \\
\text { Arribalzaga, } 1891\end{array}$ \\
\hline Melanostomini & Leucopodella & & Hull, 1949 & $\begin{array}{l}\text { Leucopodella lanei (Curran, } \\
\text { 1936) = Leucopodella bigoti } \\
\text { (Austen, 1893) }\end{array}$ \\
\hline Melanostomini & Melanostoma & & Schiner, 1860 & $\begin{array}{l}\text { Melanostoma mellinum } \\
\text { (Linnaeus, } 175^{8} \text { ) }\end{array}$ \\
\hline Melanostomini & Pelloloma & & Vockeroth, 1973 & $\begin{array}{l}\text { Pelloloma nigrifacies } \\
\text { Vockeroth, } 1973\end{array}$ \\
\hline Melanostomini & Talahua & & Fluke, 1945 & Talahua fervida (Fluke, 1945) \\
\hline Melanostomini & Xanthandrus & Androsyrphus & Thompson, 1981 & $\begin{array}{l}\text { Xanthandrus (Androsyrphus) } \\
\text { setifemoratus Thompson, } 1981\end{array}$ \\
\hline Melanostomini & Xanthandrus & Xanthandrus & Verrall, 1901 & $\begin{array}{l}\text { Xanthandrus (Xanthandrus) } \\
\text { comtus (Harris, } 1780 \text { ) }\end{array}$ \\
\hline Bacchini & Baccha & & Fabricius, 1805 & Baccha elongata (Fabricius, 1775) \\
\hline Bacchini & Eocheilosia & & Hull, 1949 & Eocheilosia ronana (Miller, 1921) \\
\hline Bacchini & Platycheirus & Carposcalis & Enderlein, 1937 & $\begin{array}{l}\text { Platycheirus (Carposcalis) steg- } \\
\text { nus (Say, 1829) }\end{array}$ \\
\hline Bacchini & Platycheirus & Pachysphyria & Enderlein, 1937 & $\begin{array}{l}\text { Platycheirus (Pachysphyria) } \\
\text { dexter (Harris, } 1780 \text { ) }\end{array}$ \\
\hline Bacchini & Platycheirus & Platycheirus & $\begin{array}{l}\text { Lepeletier \& Serville, } \\
1828\end{array}$ & $\begin{array}{l}\text { Platycheirus (Platycheirus) } \\
\text { scutatus (Meigen, 1822) }\end{array}$ \\
\hline Bacchini & Platycheirus & Tuberculanostoma & Fluke, 1943 & $\begin{array}{l}\text { Platycheirus (Tuberculanostoma) } \\
\text { antennatus (Fluke, 1943) }\end{array}$ \\
\hline Bacchini & Pyrophaena & & Schiner, 1860 & $\begin{array}{l}\text { Pyrophaena rosarum } \\
\text { (Fabricius, 1787) }\end{array}$ \\
\hline Bacchini & Rohdendorfia & & Smirnov, 1924 & $\begin{array}{l}\text { Rohdendorfia dimorpha } \\
\text { Smirnov, } 1924\end{array}$ \\
\hline Bacchini & Spazigaster & & Rondani, 1843 & $\begin{array}{l}\text { Spazigaster apennini } \text { Rondani, } \\
1843 \text { = Spazigaster ambulans } \\
(\text { Fabricius, } 1798)\end{array}$ \\
\hline Bacchini & Syrphocheilosia & & Stackelberg, 1964 & $\begin{array}{l}\text { Syrphocheilosia aterrima Stack- } \\
\text { elberg, } 1964=\text { Syrphocheilosia } \\
\text { claviventris (Strobl, 1910) }\end{array}$ \\
\hline
\end{tabular}

* Pseudoplatychirus van Doesburg, 1955 is a junior synonym of Platycheirus Le Peletier \& Audinet-Serville, 1828 and Afrostoma Skevington, Thompson \& Vockeroth, 2014 is a junior synonym of Melanostoma Schiner, 186o.

male genitalia, and without male external secondary characters as all other Melanostoma species, but with an entire metasternum.

Two morphological characters were diagnostic to separate Melanostoma and Platycheirus species (Andersson, 1970; Barkalov, 2009; Haarto \& Ståhls, 2014): the shape of the metasternum and the morphology of male genitalia, especially the shape of surstyli and postgonites. Most Platycheirus males have modified protarsi, protibiae and/or with distinctive bristles or pile tufts on profemora, but they are so variable that cannot be used as diagnostic characters to define generic groups (Vockeroth, 1990; Young et al., 2016b). In a series of papers devoted to Bacchini sensu lato, Fluke $(1937,1943,1945,1957)$ studied in deep this group of genera and was the first author to study the male genitalia of these taxa (Fluke, 1957). When male genitalia 
are compared, there are no evident differences between Melanostoma and Afrostoma. However, differences between these two taxa and Platycheirus are clear (see Fluke, 1957; Shatalkin, 1975; Vockeroth, 1990, 1992; Haarto \& Ståhls, 2014; Thompson \& Skevington, 2014; Young et al., 2016b). Platycheirus species have: bifid or bilobed surstyli with a long, slightly curved lateral lobe, and a short, stout basomedial lobe; and postgonites usually slender and recurved, sickle-shaped. On the other hand, Melanostoma species and Afrostoma have: simple, one-lobed, elongate surstyli with a small basomedial tubercle; and postgonites massive, irregular or squarish in shape. Thus, male genitalia characters do not distinguish between Afrostoma and Melanostoma.

The present COI cladogram (fig. 1) places the specimens of Melanostoma janeceki sp. nov. as sister group of Afrostoma quadripunctatum, and its topology is identical to the cladogram by Thompson \& Skevington (2014), except for the inclusion of the new Melanostoma species described here. Melanostoma janeceki sp. nov. has an entire metasternum like Afrostoma quadripunctatum and the COI analysis corroborates their close relationship. But results from the multigene analysis presented here do not support the generic concept of Afrostoma, as Afrostoma quadripunctatum is embedded within the Melanostoma species (fig. 2), as sister group of Melanostoma janeceki sp. nov. Thus, the present author recognizes Afrostoma as a junior synonym of Melanostoma, which means that there is a group of Melanostoma species with the metasternum entire, not reduced.

Afrotropical species of Melanostoma are in urgent need of a taxonomic revision. There are few published identification keys (Bezzi, 1915; Curran, 1938; Dirickx, 2001) and none of them include all the described species. The same revisionary work is needed for the Oriental Melanostoma species (Lambeck \& van Brink, 1973), and probably also in the other biogeographical regions where this genus occurs. Melanostoma species have a limited number of structural characters enough variable to be used for distinguishing species, and some of them are chromatic (Dirickx, 2001). Male genitalia in this genus are remarkably homogeneous (Dirickx, 2001) and the intraspecific variability is high, plus there are several species described based only on one sex. Thus, it is very likely that the same taxon has been described two times under different names based on different sexes or very distinct specimens of the same species. Haarto \& Ståhls (2014) showed that the DNA barcode, the $5^{\prime}$ end of the COI gene, does not help to sort out species in Melanostoma alone and the sequencing of another molecular marker, i.e., the ITS2 as in Haarto \& Ståhls (2014), is needed to characterize different species. In short, the taxonomy of Afrotropical Melanostoma has been never globally attempted, and most of the species where described before Andersson (1970) pointed out the shape of the metasternum as diagnostic for this genus. During this work, the author studied many Melanostoma specimens from different collections trying to understand the variability of this character, and found other morphologically distinct Melanostoma species with a complete metasternum (see fig. 4A, B). Consequently, there is a group of Melanostoma species in the Afrotropical Region without basolateral excavation in the metasternum as in Platycheirus, and the group has more members besides Melanostoma quadripunctatum comb. nov. and Melanostoma janeceki sp. nov. Nevertheless, the largely reduced, spearheadshaped metasternum as defined by Andersson (1970) is still a valid a diagnostic character for the genus Melanostoma outside the Afrotropical Region.

\section{Bacchines and melanostomines}

Williston (1885) was the first author to recognize and name the two groups with simple, 
unsegmented aedeagus as Bacchinae (including only Baccha) and Melonostominae (with Pyrophaena, Platycheirus and Melanostoma). Later, Williston (1887) reorganized his classification giving Melanostomini a tribe level and synonymizing Ocyptamus under Baccha. This classification was adopted by later authors (see Hull, 1949; Vockeroth, 1969) with small modifications until Vockeroth (1992), who lumped all the genera with simple, unsegmented aedeagus in Bacchini sensu lato. Before the step taken by Vockeroth (1992), Dušek \& Láska (1967) grouped Xanthandrus with Melanostoma, and Platycheirus with Rohdendorfia, Spazigaster, and Pachysphyria, leaving the genus Baccha alone in their tribe Bacchini. Thompson (1972) also divided Melanostomini into two groups of genera based on male genitalia characters and the presence or absence of modified protibiae in males: the Melanostoma group and the Platycheirus group. In a similar line of thought, Shatalkin (1975) suggested two tribes, i.e., Melanostomini (subdivided into Melanostomina and Platycheirina) and Bacchini including Baccha, but also other Syrphini genera like Allobaccha and Ocyptamus; a group defined as "an artificial aggregation” by Vockeroth (1969). Later, Kassebeer (200ob) proposed a morphological synapomorphy for the melanostomine genera previously suggested by Fluke (1943), and considered Melanostomini monophyletic.

Male genitalia characters have been used to group these taxa. Thompson (1972) divided Melanostomini into the Melanostoma group (simple legs in males, with triangular or quadrate postgonites and elongate, usually not forked, surstyli) and the Platycheirus group (modified protibiae in males, sickleshaped postgonites and forked surstyli). Later, Shatalkin (1975) used the same argument for his subtribes Melanostomina and Platycheirina within Melanostomini. Based on published literature (Fluke, 1957; Dušek \& Láska, 1967; Thompson, 1972; Vockeroth, 1973, 1990,
1992; Shatalkin, 1975; Ôhara, 1980; Claussen, 1987; Dirickx, 2001; Borges \& Pamplona, 2003; Barkalov, 2007; Barkalov \& Nielsen, 2010; Haarto \& Ståhls, 2014; Thompson \& Skevington, 2014; Young et al., 2016b) sickle-shaped postgonites and forked or bilobed surstyli are present in all Platycheirus subgenera, although some Carposcalis species do not have sickle-shaped postgonites, but triangular postgonites like a scalene triangle with a broad base, or their surstyli are not evidently bilobed. The species Platycheirus (Tuberculanostoma) antennatum (Fluke, 1943) is also an exception. The two species described as Pseudoplatychirus also have bilobed surstyli and sickle-shaped postgonites, but smaller, more compressed.

Eocheilosia has globular surstyli and sickleshaped postgonites, and Syrphocheilosia claviventris (Strobl, 1910) has one-lobed surstyli and elongate, one-lobed postgonites. Spazigaster ambulans (Fabricius, 1798) has sickleshaped postgonites but one-lobed surstyli, while Rohdendorfia species have one-lobed, sickle-shaped surstyli curved ventrally, and bilobed postognites with dorsal lobe hookshaped (Mengual \& Barkalov, 2019). Pyrophaena rosarum (Fabricius, 1787) has sickle-shaped postgonites but broad, elongate, one-lobed surstyli. Pyrophaena granditarsa (Forster, 1771) also has elongate, not bilobed surstyli with a small basomedial tubercle, but solid, triangular postgonites. Pyrophaena rufigaster (Vockeroth, 1990) has one-lobed surstyli and postgonites with three dorsal hook-shaped protuberances, very similar to Platycheirus (Platycheirus) coracinus Vockeroth, 1990, a member of the Platycheirus pictipes species group sensu Young et al. (2016b). Final placement of these species is unclear and is beyond the scope of this study.

Regarding the genus Baccha, B. elongata (Fabricius, 1775) have massive postognites with two processes pointed postero-ventrally and elongate surstyli with a small basomedial 
tubercle, which could be interpreted as bilobed surstyli.

Argentinomyia, Leucopodella, Pelloloma, Melanostoma, and Xanthandrus species have one-lobed, elongate surstyli and postgonites massive (solid), irregular, elongate, triangular or squarish in shape. Some Argentinomyia species present surstyli very variable in shape, but nothing like a bilobed surstylus. Talahua fervida, however, has strongly modified male genitalia with elongate postgonites and surstyli three to four times longer than wide.

Cytotaxonomy, although scarce, can be used as an alternative data source for these groupings. On this topic, Leucopodella has five chromosome pairs and Argentinomyia species have four or five chromosome pairs (Boyes \& van Brink, 1964; Boyes et al., 1971, 1973). Melanostoma, Xanthandrus, Platycheirus sensu stricto and Platycheirus (Carposcalis) has four chromosome pairs, but different in structure (Boyes \& van Brink, 1964; Boyes et al., 1971). On the other hand, Baccha species have three (B. elongata and B. obscuripennis Meigen, 1822) or four (Baccha maculata Walker, 1852) pairs of chromosomes. Boyes et al. (1971) pointed out that the karyotypes of Carposcalis and Platycheirus are very similar, but quite different from Melanostoma and Xanthandrus, and they suggested two distinct groups although all have $2 n=8$. Some exceptions occur, e.g., Xanthandrus bucephalus (Wiedeman, 1830) with $2 n=10$, as Bacchini sensu lato has high karyological variation.

Based on previous studies and the results presented here, the current concept of Bacchini sensu lato is not monophyletic. Syrphinae genera with simple, unsegmented aedeagus are divided into two groups as follows: Melanostoma and related genera, and Baccha, plus Platycheirus and related genera. Although Shatalkin (1975) stated that the male genitalia of Baccha is reminiscent to genitalia of Melanostoma and Leucopodella, the genus Baccha has been resolved as sister group of Platycheirus and related genera based on the latest molecular analyses (Mengual, 2015; Mengual et al., 2015; Young et al., 2016a; this study). See table 2 for a list of genera and subgenera of Bacchini stat. rev. and Melanostomini stat. rev. and a new generic classification based on the present results.

\section{Acknowledgements}

I am very grateful to Štěpán Janeček and Anna Vlašánková for letting me study the material they collected in Cameroon and for a very fruitful collaboration. I thank Nigel Wyatt (BMNH), Ben Brugge and Pasquale Ciliberti (NBC), and Christophe Daugeron and Emmanuel Delfosse (MNHN) for letting me study material in their care. I am very indebted to all colleagues and collectors that made specimens available for so many years; without them this study would not have been possible. This research received support from the SYNTHESYS Project (http://www.synthesys.info/, grant FR-TAF-5931), which is financed by European Community Research Infrastructure Action under the $\mathrm{FP}_{7}$ "Capacities" Program.

\section{References}

Andersson, H. (1970) Taxonomic notes on the genera Platycheirus and Melanostoma (Dipt., Syrphidae) with lectotype designations. Entomol. Scand., 1, 236-240. doi:10.1163/187631270X00087

Barkalov, A.V. \& Nielsen, T.R. (2010) Revision of the genus Rohdendorfia Smirnov, 1924 (Diptera, Syrphidae). Norw.J. Entomol., 57, 154-161. http:// www.entomologi.no/journals/nje/2010-2/pdf/ nje-vol57-no2-barkalov-nielsen.pdf

Barkalov, A.V. (2007) A genus and a species of hover-flies, new for the Russian fauna (Diptera, Syrphidae). Entomol. Rev., 87, 930-933. doi:10.1134/Soo13873807070172 
Barkalov, A.V. (2009) Hover-flies of the genus Melanostoma closely related to Melanostoma dubium (Diptera, Syrphidae). Entomol. Rev., 89, 1013-1017.

Bergh, J.C. \& Short, B.D. (2008) Ecological and life-history notes on syrphid predators of woolly apple aphid in Virginia, with emphasis on Heringia calcarata. BioControl, 53, 773-786. doi:10.1007/s10526-007-9114-o

Bezzi, M. (1915) The Syrphidae of the Ethiopian Region. British Museum (N.H.), London.

Bigot, J.M.F. (1883) Diptères nouveaux ou peu connus. 21e partie. XXXII. Syrphidi ( $1^{\mathrm{re}}$ partie). Ann. Soc. Entomol. Fr., Ser. 6, 3, 221-258.

Borges, Z.M. \& Pamplona, D.M. (2002) Revision of the Neotropical Xanthandrus Verral (Diptera, Syrphidae). Rev. Bras. Entomol., 47, 155-167. doi:10.159o/Soo85-56262003000200002

Boyes, J.W., Boyes, B.C., van Brink, J.M. \& Vockeroth, J.R. (1973) Cytotaxonomy of South American Syrphidae (Diptera: Syrphidae). Genet., 44, 368-415. doi:10.1007/BFoo161313

Boyes, J.W., van Bring, J.M. \& Boyes, B.C. (1971) Chromosomes of Syrphinae (Diptera: Syrphidae). The Genetics Society of Canada, Ottawa, Canada.

Boyes, J.W. \& van Brink, J.M. (1964) Chromosomes of Syrphidae I. Variations in Karyotype. Chromosoma, 15, 579-59o.

Bugg, R.L., Colfer, R.G., Chaney, W.E., Smith, H.A. \& Cannon, J. (2008) Flower flies (Syrphidae) and other biological control agents for aphids in vegetable crops. UC ANR, Publication 8285 . http://anrcatalog.ucanr.edu/pdf/8285.pdf

Claussen, C. (1987) Syrphocheilosia claviventris (Strobl, 1910) und Cheilosia laeviseta nom.n. (Diptera: Syrphidae), mit taxonomischen Anmerkungen und neuen Nachweisen aus den Alpen. Entomol. Z., 97, 337-352.

Cumming, J.M. \& Wood, D.M. (2017) Adult morphology and terminology. In: A.H. Kirk-Spriggs \& B.J. Sinclair (Eds) Manual of Afrotropical Diptera. Volume 1. Suricata 4, pp. 89-133. South African National Biodiversity Institute, Pretoria.
Curran, C.H. (1938) Records and descriptions of African Syrphidae II (Diptera). Am. Mus. Nov., 1010, 1-20. http://hdl.handle.net/2246/2208

Darriba, D., Taboada, G.L., Doallo, R. \& Posada, D. (2012) jModelTest 2: more models, new heuristics and parallel computing. Nat. Methods, 9, 772. doi:10.1038/nmeth.2109

Dirickx, H.G. (2001) Notes sur le genre Melanostoma Schiner, 1860 (Diptera, Syrphidae) à Madagascar et les îles voisines avec descriptions de cinq espèces nouvelles. Rev. Suisse Zool., 108, 993-1029. doi:10.5962/bhl.part.80173

Downes, M.F., Skevington, J.H. \& Thompson, F.C. (2017) A new ant inquiline flower fly (Diptera: Syrphidae: Pipizinae) from Australia. Aust. Entomol., 44, 29-38.

Doyle, J.J. (1992) Gene trees and species trees: molecular systematics as one-character taxonomy. Syst. Bot., 17, 144-163. https://www.jstor.org/ stable/2419070

Dumbardon-Martial, E. (2016) Pollen feeding in the larva of Toxomerus pulchellus (Diptera, Syrphidae). Bull. Soc. Entomol. Fr., 121, 413-420. doi:10.1080/00222930802610576

Dušek, J. \& Láska, P. (1967) Versuch zum Aufbau eines natürlichen Systems mitteleuropäischer Arten der Unterfamilie Syrphinae (Diptera). Acta Sc. Nat. Brno, 1, 349-39o.

Fleischmann, A., Rivadavia, F., Gonella, P.M., Pérez-Bañón, C., Mengual, X. \& Rojo, S. (2016) Where is my food? Brazilian flower fly steals prey from carnivorous sundews in a newly discovered plant-animal interaction. PLoS ONE, 11, eo15390o. doi:10.1371/journal.pone.015390o

Fluke, C.L. (1937) New South American Syrphidae (Diptera). Am. Mus. Nov., 941, 1-14. http://hdl .handle.net/2246/2182

Fluke, C.L. (1943) A new genus and new species of Syrphidae (Diptera) from Ecuador. Ann. Entomol. Soc. Am., 36, 425-431. doi:10.1093/ aesa $/ 36.3 .425$

Fluke, C.L. (1945) The Melanostomini of the Neotropical Region (Diptera, Syrphidae). Am. Mus. Nov., 1272,1-29.http://hdl.handle.net/2246/3720 
Fluke, C.L. (1957) A study of the male genitalia of the Melanostomini (Diptera-Syrphidae). Trans. Wis. Acad. Sci. Arts Lett., 46, 261-279.

Haarto, A. \& Ståhls, G. (2014) When mtDNA COI is misleading: congruent signal of ITS2 molecular marker and morphology for North European Melanostoma Schiner, 1860 (Diptera, Syrphidae). ZooKeys, 431, 93-134. doi:10.3897/ zookeys.431.7207

Hebert, P.D.N., Cywinska, A., Ball, S.L. \& J.R. deWaard (2003a) Biological identifications through DNA barcodes. Proc. R. Soc. Lond. B. Biol. Sci., 270, 313-321. doi:10.1098/rspb.2002.2218

Hebert, P.D.N. \& Gregory, T.R. (2005) The promise of DNA barcoding for taxonomy. Syst. Biol., 54, 852-859. doi:10.1080/10635150500354886

Hebert, P.D.N., Ratnasingham, S. \& DeWaard, J.R. (2003b) Barcoding animal life: Cytochrome C oxidase subunit 1 divergences among closely related species. Proc. R. Soc. Lond. B. Biol. Sci., 270, S96-S99. doi:10.1098/rsbl.2003.0025

Hippa, H. \& Ståhls, G. (2005) Morphological characters of adult Syrphidae: descriptions and phylogenetic utility. Acta Zool. Fenn., 215, 1-72.

Huelsenbeck, J.P. \& Ronquist, F. (2001) MrBayes: Bayesian inference of phylogenetic trees. Biometrics, 17, 754-755. doi:10.1093/bioinfor matics/17.8.754

Hull, F.M. (1949) The morphology and interrelationship of the genera of syrphid flies, recent and fossil. Trans. Zool. Soc. London, 26, 257-408. doi:10.1111/j.1096-3642.1949.tboo224.x

Huo, K-K. (2014) Spazigasteroides a new genus from China with a black face and scutellum in the Syrphini (Diptera: Syrphidae). Zootaxa, 3755, 230-240. doi:10.11646/zootaxa.3755·3.2

Inouye, D., Larson, B.M.H., Ssymank, A. \& Kevan, P.G. (2015) Flies and flowers III: Ecology of foraging and pollination. J. Pollinat. Ecol., 16, 115-133.

Kassebeer, C.F. (2000a) Revision der Gattung Pelloloma Vockeroth, 1973 (Diptera, Syrphidae), mit der Beschreibung neuer Arten aus Zentralafrika. Dipteron, 3, 159-166.
Kassebeer, C.F. (200ob) Afroxanthandrus gen. nov. (Diptera, Syrphidae), eine neue Gattung der Syrphinae aus Westafrika. Dipteron, 3, 149-158.

Kjer, K.M. (1995) Use of rRNA secondary structure in phylogenetic studies to identify homologous positions: an example of alignment and data presentation from the frogs. Mol. Phylogenet. Evol., 4, 314-330. doi:10.1006/mpev.1995.1028

Lambeck, H.J.P. \& van Brink, J.M. (1973) Contribution to the knowledge of the taxonomy, faunal composition and cytology of the syrphid flies (Diptera: Syrphidae) of Kashmir (India). I. Taxonomic account and faunal composition. Genen. Phaenen., 16, 87-100.

Lardé, G. (1989) Investigation on some factors affecting larval growth in a coffee-pulp bed. Biol. Wastes, 30, 11-19. doi:10.1016/0269-7483(89) 90139-0

Láska, P., Mazánek, L. \& Bičík, V. (2013) Key to adults and larvae of the genera of European Syrphinae (Diptera, Syrphidae). Čas. Slez. zemského muz., 62, 193-206. doi:10.2478/cszma-2013-0021

Martínez-Falcón, A.P., Marcos-García, M.A., Moreno, C.E. \& Rotheray, G.E. (2012) A critical role for Copestylum larvae (Diptera, Syrphidae) in the decomposition of cactus forests. J. Arid Environ., 78, 41-48. doi:10.1016/j.jaridenv.2011. 10.010

Mengual, X., Ståhls, G., Láska, P., Mazánek, L. \& Rojo, S. (2018) Molecular phylogenetics of the predatory lineage of flower flies EupeodesScaeva (Diptera: Syrphidae), with the description of the Neotropical genus Austroscaeva gen. nov. J. Zoo. Syst. Evol. Research, 56, 148-169. doi:10.1111/jzs.12212

Mengual, X., Ståhls, G. \& Rojo, S. (2008a) First phylogeny of predatory flower flies (Diptera, Syrphidae, Syrphinae) using mitochondrial COI and nuclear28SrRNAgenes: conflictand congruence with the current tribal classification. Cladistics, 24, 543-562. doi:10.1111/j.1096-0031.2008.00200.x Mengual, X., Ståhls, G. \& Rojo, S. (2008b) Molecular phylogeny of Allograpta (Diptera, Syrphidae) reveals diversity of lineages and non-monophyly 
of phytophagous taxa. Mol. Phylogenet. Evol., 49, 715-727. doi:10.1016/j.ympev.2008.09.011

Mengual, X., Ståhls, G. \& Rojo, S. (2012) Is the mega-diverse genus Ocyptamus (Diptera, Syrphidae) monophyletic? Evidence from molecular characters including the secondary structure of 28S rRNA. Mol. Phylogenet. Evol., 62, 191-205. doi:10.1016/j.ympev.2011.09.014

Mengual, X., Ståhls, G. \& Rojo, S. (2015) Phylogenetic relationships and taxonomic ranking of pipizine flower flies (Diptera: Syrphidae) with implications for the evolution of aphidophagy. Cladistics, 31, 491-508. doi:10.1111/cla.12105

Mengual, X. \& Barkalov, A.V. (2019) Two new species of Rohdendorfia (Diptera: Syrphidae) from Central Asia. Acta Entomol. Mus. Nat. Pragae, 59, 325-336. doi:10.2478/aemnp-2019-0025

Mengual, X. \& Thompson, F.C. (2011) Carmine cochineal killers: the flower fly genus Eosalpingogaster Hull (Diptera: Syrphidae) revised. Syst. Entomol., 36, 713-731. doi:10.1111/j.1365-3113 $.2011 .00588 . \mathrm{x}$

Mengual, X. (2015) The systematic position and phylogenetic relationships of Asiobaccha Violovitsh (Diptera, Syrphidae).J. Asia-Pac. Entomol., 18, 397-408. doi:10.1016/j.aspen.2015.03.010

Miller, M.A., Pfeiffer, W. \& Schwartz, T. (2010) Creating the CIPRES Science Gateway for inference of large phylogenetic trees. In: Proceedings of the Gateway Computing Environments Workshop $(G C E)$, 14 Nov 2010, pp. 1-8. New Orleans, LA.

Miranda, G.F.G. \& Moran, K. (2017) The female abdomen and genitalia of Syrphidae (Diptera). Insect Syst. Evol., 48, 157-201. doi:10.1163/1876312 $\mathrm{X}-48022153$

Morales, G.E. \& Wolff, M. (2010) Insects associated with the composting process of solid urban waste separated at the source. Rev. Bras. Entomol., 54, 645-653. doi:10.1590/Soo8556262010000400017

Nelson, E.H., Hogg, B.N., Mills, N.J. \& Daane, K.M. (2012) Syrphid flies suppress lettuce aphids. BioControl, 57, 819-826. doi:10.1007/ s10526-012-9457-Z
Nichols, R. (2001) Gene trees and species trees are not the same. Trends Ecol. Evol., 16, 358-364. doi:10.1016/S0169-5347(01)02203-o

Nielsen, T.R. \& Barkalov, A.V.(2017)A revision of and key to the Holarctic and Oriental Platycheirus manicatus group species (Diptera, Syrphidae). Norw. J. Entomol., 64, 28-52.

Nielsen, T.R. (2004) European species of the Platycheirus ambiguus group (Diptera, Syrphidae), with description of new species. Volucella, 7 , 1-30.

Nielsen, T.R. (2014) Synopsis of the Platycheirus ambiguus species group (Diptera, Syrphidae), with description of Platycheirus arnei sp. n. and a preliminary key to the species. Norw. J. Entomol., 61, 57-75.

Nishida, K., Rotheray, G. \& Thompson, F.C. (2002) First non-predaceous syrphine flower-fly (Diptera: Syrphidae): a new leaf-mining Allograpta from Costa Rica. Stud. Dipterol., 9, 421-436.

Ôhara, K. (1980) The genus Platycheirus Lepeletier and Serville, 1828 (Diptera, Syrphidae) of Japan, with descriptions of three new species. Esakia, 15, 97-142. https://catalog.lib.kyushu-u.ac.jp/ opac_download_md/2405/97.pdf

Pauli, T., Burt, T., Meusemann, K, Bayless, K,. Donath, A., Podsiadlowski, L., Mayer, C., Kozlov, A., Vasilikopoulos, A., Liu, S., Zhou, X., Yeates, D., Misof, B., Peters, R.S. \& Mengual, X. (2018) New data, same story: phylogenomics does not support Syrphoidea (Diptera: Syrphidae, Pipunculidae). Syst. Entomol., 43, 447-459. doi:10.1111/ syen. 12283

Pérez-Lachaud, G., Jervis, M.A., Reemer, M. \& Lachaud, J.-P. (2014) An unusual, but not unexpected, evolutionary step taken by syrphid flies: the first record of true primary parasitoidism of ants by Microdontinae. Biol. J. Linn. Soc., 111, 462-472. doi:10.1111/bij.12220

Posada, D. \& Buckley, T. (2004) Model selection and model averaging in phylogenetics: advantages of Akaike information criterion and Bayesian approaches over likelihood ratio tests. Syst. Biol., 53, 793-808. doi:10.1080/10635150490522304 Downloaded from Brill.com04/26/2023 09:04:30AM 
Rambaut, A., Drummond, A.J., Xie, D., Baele, G. \& Suchard, M.A. (2018) Posterior summarisation in Bayesian phylogenetics using Tracer 1.7. Syst. Biol., 67, 901-904. doi:10.1093/sysbio/syyo32

Rambaut, A. (2018) FigTree v. 1.4.4: Tree Figure Drawing Tool.http://tree.bio.ed.ac.uk/software/ figtree/

Reemer, M. \& Rotheray, G.E. (2009) Pollen feeding larvae in the presumed predatory syrphine genus Toxomerus Macquart (Diptera, Syrphidae). J. Nat. Hist., 43, 939-949. doi: 10.1080/00222930802610576

Ricarte, A., Marcos-García, M.A. \& Moreno, C.E. (2011) Assessing the effects of vegetation type on hoverfly (Diptera: Syrphidae) diversity in a Mediterranean landscape: implications for conservation. J. Insect Conserv., 15, 865-877. doi:10.1007/s10841-011-9384-9

Rojo, S., Gilbert, F., Marcos-García, M.A., Nieto, J.M. \& Mier, M.P. (2003) A World Review of Predatory Hoverflies (Diptera, Syrphidae: Syrphinae) and Their Prey. Centro Iberoamericano de la Biodiversidad (CIBIO), Alicante.

Ronquist, F. \& Huelsenbeck, J.P. (2003) MrBayes 3: Bayesian phylogenetic inference under mixed models. Bioinformatics, 19, 1572-1574. doi: 10.1093/bioinformatics/btg18o

Ronquist, F., Huelsenbeck, J.P. \& van der Mark, P. (2005) MrBayes 3.1 Manual. Retrieved from http://mrbayes.csit.fsu.edu/manual.php/ (accessed 12 March 2019)

Rotheray, G.E. (1993) Colour Guide to Hoverfly Larvae (Diptera, Syrphidae) in Britain and Europe. Dipterists Digest No. 9, UK.

Rotheray, G.E. \& Gilbert, F. (1989) The phylogeny and systematics of European predacious Syrphidae (Diptera) based on larval and puparial stages. Zool. J. Linn. Soc., 95, 29-70. doi: 10.1111/j.1096-3642.1989.tbo2222.x

Rotheray, G.E. \& Gilbert, F. (1999) Phylogeny of Palaearctic Syrphidae (Diptera): evidence from larval stages. Zool. J. Linn. Soc., 127, 1-112. doi:10.1111/j.1096-3642.1999.tbo1305.x

Rotheray, G.E. \& Gilbert, F. (2011) The Natural History of Hoverflies. Forrest Text, Ceredigion.
Rozo-Lopez, P. \& Mengual, X. (2015) Mosquito species (Diptera, Culicidae) in three ecosystems from the Colombian Andes: identification through DNA barcoding and adult morphology. ZooKeys, 513, 39-64. doi:10.3897/ zookeys.513.9561

Sabrosky, C.W. (1999) Family-group names in Diptera. An annotated catalog. Myia, 10, 1-576.

Schmidt, M.H., Thewes, U., Thies, C. \& Tscharntke, T. (2004) Aphid suppression by natural enemies in mulched cereals. Entomol. Exp. Appl., 113, 8793. doi:10.1111/j.0013-8703.2004.00205.X

Shatalkin, A.I. (1975) A taxonomic analysis of the hover flies (Diptera, Syrphidae). I. Entomol. Rev., 54, 117-125 (Originally published in Russian in Entomol. obozr., 54, 164-175).

Skevington, J.H. \& Thompson, F.C. (2012) Review of New World Sericomyia (Diptera: Syrphidae), including description of a new species. Can. Entomol., 144, 1-32. doi:10.4039/tce.2012.24

Sommaggio, D. (1999) Syrphidae: can they be used as environmental bioindicators. $A g$ ric. Ecosyst. Environ., 74, 343-356. doi:10.1016/ So167-8809(99)00042-0

Sommaggio, D. \& Burgio, G. (2014) The use of Syrphidae as functional bioindicator to compare vineyards with different managements. Bull. Insectol., 67, 147-156.

Speight, M.C.D. (1987) External morphology of adult Syrphidae (Diptera). Tijdschr. entomol., 130, 141-175.

Speight, M.C.D. (2018) Species accounts of European Syrphidae, 2018. In: Syrph the Net, the database of European Syrphidae (Diptera), vol. 103. Syrph the Net publications, Dublin.

Ssymank, A. \& Kearns, C. (2009) Flies-pollinators on two wings. In: A. Ssymank, A. Hamm \& M.Vischer-Leopold(Eds) Caringfor PollinatorsSafeguarding Agro-Biodiversity and Wild Plant Diversity, pp. 39-52. Bundesamt für Naturschutz, Bonn.

Ståhls, G., Hippa, H., Rotheray, G., Muona, J. \& Gilbert, F. (2003) Phylogeny of Syrphidae (Diptera) inferred from combined analysis of molecular and morphological characters. Downloaded from Brill.com04/26/2023 09:04:30AM via free access 
Syst. Entomol., 28, 433-450. doi:10.1046/j.13653113.2003.00225.X

Thompson, F.C., Rotheray, G.E. \& Zumbado, M. (2010) Family Syrphidae. In: B. Brown, A. Borkent, J.M. Cumming, D.M. Wood, N.E. Woodley \& M.A. Zumbado (Eds) Manual of Central American Diptera, Volume 2, pp. 763792. NRC Press, Ottawa.

Thompson, F.C. \& Rotheray, G.E. (1998) Family Syrphidae. In: L. Papp \& B. Darvas (Eds) Contributions to a Manual of Palaearctic Diptera, Volume 3, pp. 81-139. Science Herald, Budapest.

Thompson, F.C. \& Skevington, J.H. (2014) Afrotropical flower flies (Diptera: Syrphidae). A new genus and species from Kenya, with a review of the melanostomine group of genera. Zootaxa, 3847, 97-114. doi:10.11646/zootaxa.3847.1.5

Thompson, F.C., Vockeroth, J.R. \& Sedman, Y.S. (1976) Family Syrphidae. A catalogue of the Diptera of the American South of the United States, 46, 1-195. https://repository.si.edu/handle/ $10088 / 17070$

Thompson, F.C. \& Vockeroth, J.R. (1989) Family Syrphidae. In: N.L. Evenhuis (Ed.) Catalog of the Diptera of the Australasian and Oceanian Regions, pp. 437-458. Bishop Museum Special Publication vol. 86, Hawaii.

Thompson, F.C. (1969) A new genus of microdontine flies (Diptera: Syrphidae) with notes on the placement of the subfamily. Psyche, 76, 74-85. doi:10.1155/1969/62102

Thompson, F.C. (1972) A new Platycheirus from New Zealand. First record of a melanostomine syrphid fly associated with ants. N. Z. J. Sci., 15, 77-84. https://repository.si.edu/handle/ 10088/17048

Thompson, F.C. (1999) A key to the genera of the flower flies of the Neotropical Region including the descriptions of genera and species and a glossary of taxonomic terms. Contrib. Entomol. Int., 3, 319-378. https://repository.si.edu/ handle/10088/17492

Thompson, F.C. (2008) A conspectus of New Zealand flower flies (Diptera: Syrphidae) with the description of a new genus and species. Zootaxa 1716, 1-20. doi:10.5281/zenodo.181009

Thompson, F.C. (2019) A new flower fly from the Afrotropics (Diptera: Syrphidae). Entomol. Mon. Mag. 155, 159-162. doi:10.31184/ Moo138908.1553.3967

Tscharntke, T., Klein, A.M., Kruess, A., SteffanDewenter, I. \& Thies, C. (2005) Landscape perspectives on agricultural intensification and biodiversity-ecosystem service management. Ecol. Lett., 8, 857-874. doi:10.1111/j.1461-0248 $.2005 .00782 . x$

Ureña, O. \& Hanson, P. (2010) A fly larva (Syrphidae: Ocyptamus) that preys on adult flies. Rev. Biol. Trop., 58, 1157-1163. doi:10.15517/rbt. v58i4.5401

van Doesburg, P.H. Sr. (1955) Report on the Syrphid Flies, collected by the "Fourth Dutch Karakorum Expedition, 1935". Beaufortia, 5, 47-51. https:// www.repository.naturalis.nl/record/505205 van Steenis, J., Young, A.D., Ssymank, A.M., Wu (Bill), T.-H., Shiao, S.-F. \& Skevington, J.H. (2019) The species of the genus Platycheirus Lepeletier \& Serville, 1828 (Diptera, Syrphidae) from Taiwan, with a discussion on intersex specimens. J. Asia-Pac. Entomol., 22, 281-295. doi:10.1016/j .aspen.2018.12.004

Vlašánková, A., Padyšáková, E., Bartoš, M., Mengual, X., Janečková, P. \& Janeček, Š. (2017) The nectar spur is not only a simple specialization for long-proboscid pollinators. New Phytol., 215, 1574-1581. doi:10.1111/nph.14677

Vockeroth, J.R. (1969) A revision of the genera of the Syrphini (Diptera, Syrphidae). Mem. Ent. Soc. Can., 62, 1-176.

Vockeroth, J.R. (1973) Some new or uncommon Syrphini (Diptera: Syrphidae) from Southern Africa. Ann. Natal Mus., 21, 595-607. https://hdl .handle.net/10520/AJA03040798_646

Vockeroth, J.R. (1990) Revision of the Nearctic species of Platycheirus (Diptera, Syrphidae). Can. Entomol., 122, 659-766. doi:10.4039/Ent122659-7 Vockeroth, J.R. (1992) The flower flies of the Subfamily Syrphinae of Canada, Alaska, and 
Greenland (Diptera: Syrphidae). The Insects and arachnids of Canada, part 18. Centre for Land and Biological Resources Research, Ottawa. http://publications.gc.ca/pub?id=9. $811395 \&$ sl $=0$

Vockeroth, J.R. \& Thompson, F.C. (1987) 52. Syrphidae. In: J.F. McAlpine (Ed.) Manual of Nearctic Diptera, Volume 2, pp. 713-743. Agriculture Canada, Ottawa.

Weng, J.L. \& Rotheray, G.E. (2008) Another nonpredaceous syrphine flower fly (Diptera: Syrphidae): pollen feeding in the larva of Allograpta micrura. Stud. Dipterol., 15, 245-258.

Williston, S.W. (1885) On classification of North American Diptera. Bull. Brooklyn Entomol. Soc., 7, 129-139.

Williston, S.W. (1887) Synopsis of the North American Syrphidae. Bull. U.S. Nat. Mus. (1886), 31, xxx + 1-335. doi:10.5479/si.03629236.31.i

Wirth, W.W., Sedman, Y.S. \& Weems, H.V. (1965) Family Syrphidae. In: A. Stone, C.W. Sabrosky, W.W. Wirth, R.H. Foote \& J.R. Coulson (Eds) A Catalog of the Diptera of America North of Mexico, pp. 557-625. Agricultural Research Service, United States Department of Agriculture, Washington, DC.

Young, A.D., Lemmon, A.R., Skevington, J.H., Mengual, X., Ståhls, G., Reemer, M., Jordaens, K., Kelso, S., Lemmon, E.M., Hauser, M., De Meyer, M., Misof, B. \& Wiegmann, B.M. (2016a) Anchored enrichment dataset for true flies (order Diptera) reveals insights into the phylogeny of flower flies (family Syrphidae). BMC Evol. Biol., 16,143 .
Young, A.D., Marshall, S.A. \& Skevington, J.H. (2016b) Revision of Platycheirus Lepeletier and Serville (Diptera: Syrphidae) in the $\mathrm{Ne}-$ arctic north of Mexico. Zootaxa, 4082, 1-317. doi:10.11646/zootaxa.4082.1.1

Zimina, L.V. (1958) New genus of hover-flies (Diptera, Syrphidae) indigenous to the USSR. Entomol. obozr., 37, 206-207. [In Russian]

Zuijen, M.P. \& Nishida, K. (2011) Description of life history and immature stages of phytophagous flower fly, Allograpta zumbadoi Thompson (Diptera: Syrphidae: Syrphinae). Stud. dipterol., 17, 37-51.

Zwickl, D.J. (2006) Genetic algorithm approachesfor the phylogenetic analysis of large biological sequence datasets under the Maximum Likelihood criterion. PhD Thesis, The University of Texas at Austin, USA. http://hdl.handle.net/2152/2666 Zwickl, D.J. (2011) GARLI (Genetic Algorithm for Rapid Likelihood Inference) version 2.or. Retrieved from https://code.google.com/archive/p/garli/ downloads (accessed 12 March 2019)

RECEIVED: 26 APRIL 2019 | REVISED AND ACCEPTED: 19 NOVEMBER 2019

EDITORS: F. RHEBERGEN \& H. DE JONG 